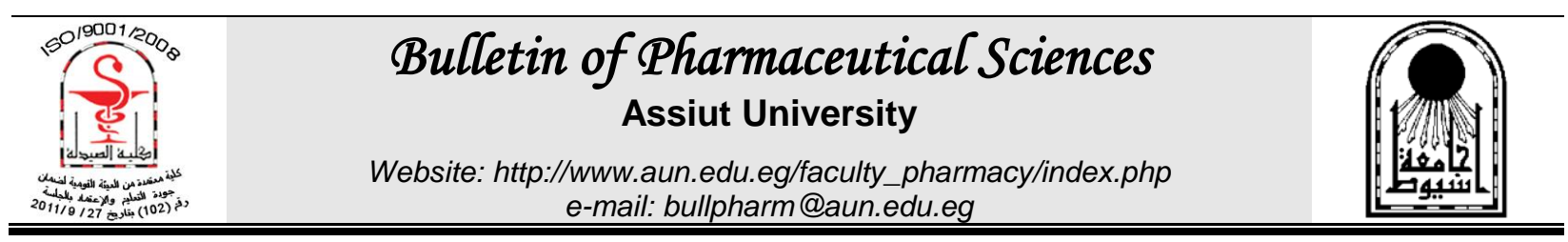

\title{
BOTANICAL PROFILING OF GMELINA PHILIPPENSIS CHAM., CULTIVATED IN EGYPT
}

\author{
H. M. Sayed, A. S. Ahmed, I. S. A. Khallaf and A. Asem* \\ Department of Pharmacognosy, Faculty of Pharmacy, Assiut University, Assiut, Egypt
}

\begin{abstract}
Gmelina philippensis Cham. Family Lamiaceae, sometimes placed in family Verbenaceae, is one of the ornamental and medicinal plants, known as parrot's peak, as it produces yellow flowers from a long tube-shaped structure comprised of overlapping bracts. It is a sprawling thorny shrub that was formerly taxonomically classified to family Verbenaceae. It is native to Philippines, Burma and distributed in tropical and subtropical countries. The present investigation attempts to study the pharmacognostical features of the aerial parts (leaves, stems and inflorescence) of Gmelina philippensis Cham. which could be helpful in authentication of the plant and establishing pharmacognostical standard measurements which help in its identification in both entire and powdered forms.
\end{abstract}

\section{INTRODUCTION}

Family Lamiaceae is one of the six largest angiosperm families comprising approximately 180 genera and more than 3500 species distributed throughout the world ${ }^{1-4}$.

The most recent classification proposed by Harley $^{5}$, recognized seven subfamilies within the family Lamiaceae (Ajugoideae, Lamioideae, Neptoideae, Prostantheroideae, Scutellaroideae, Symphorematoideae and Viticoideae). Different studies, phylogenetic and taxonomic, proved the transfer of subfamily Viticoideae from family Verbenaceae to Lamiaceae ${ }^{6}$. The transfer of the genus Gmelina from Verbenaceae to Lamiaceae was also published by The International Plant Names Index ${ }^{7}$ and finally by the Kew Garden Plant List ${ }^{8}$. The genus Gmelina comprises about 40 species $^{9}$ and is widely distributed in the tropical and subtropical regions of Australia, Asia and Africa $^{10 \& 11}$. It is native to Philippines, East Cambodia, Central and South Vietnam ${ }^{9}$. The genus Gmelina was first described by Linnaeus in $1753^{9}$ on the basis of one species Gmelina asiatica $\mathrm{L}$. It was named after Johann George Gmelin (1709-1755), a German botanist of Tübingen'. Members of the genus Gmelina have been commonly used by natives for many traditional purposes. In India the root of Gmelina arborea was used as stomachic, laxative and in abdominal pain ${ }^{12}$. The root of Gmelina asiatica was also used as expectorant and demulcent ${ }^{12}$. In Peninsular Malaysia, the fruits are mixed with lime and applied externally to the throat as remedy for cough, while the leaves and root of Gmelina philippensis were used as remedy for rheumatism ${ }^{11}$. A variety of secondary metabolites as iridoids ${ }^{13}$, flavonoids ${ }^{14}$, phenyl propanoids and ethanoids ${ }^{15}$, sterols, terpenes ${ }^{16}$, volatile oils ${ }^{17}$ and lignans ${ }^{18}$ have been reported from different Gmelina species. According to the available literature nothing was traced concerning Pharmacognostical study of Gmelina philippensis Cham., cultivated in Egypt, that encouraged the authors to carry out a comprehensive study of the selected plant. Herein it is the first report for a botanical study of the leaves, stems and inflorescence of the plant under investigation, which could be a useful tool for its authentication.

A genetic study of the plant under investigation against other Labiaceous plant samples was carried out by the authors (under publication) and supported that genus Gmelina is a member of the family Lamiaceae ${ }^{19}$. 
Gmelina philippensis Cham. (Fig. 1A) is a climbing shrub reaching $(2-3.5 \mathrm{~m})$ height. The stem is cylindrical, monopodially branched, twigs carry spines up to $(1-2 \mathrm{~cm})$ in length, leaves are elliptic to obovate, sometimes shallowly 3-lobed (duckfoot). Inflorescence is terminal with yellow slightly fragrant flowers, flowering in April-July. Fruits are yellow, ovoid to obovoid, drupe and appear in JuneAugust.

\section{Taxonomy}

Gmelina philippensis Cham. belongs to Kingdom: Plantae, Phylum: Tracheophyta, Division: $\quad$ Spermatophyta, Class: Angiospermae, Subclass: Dicotyledoneae, Order: Lamiales, Family: Lamiaceae, Subfamily: Viticoideae, Genus: Gmelina, Species: philippensis Cham. Synonyms: $G$. hystrix Schult. ex Kurz ${ }^{20-22}$.

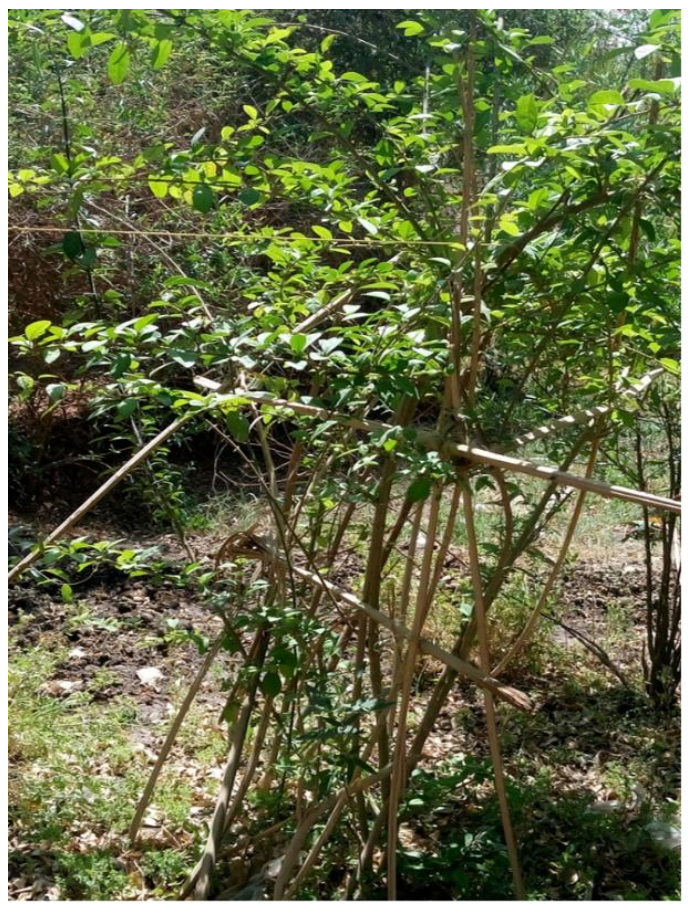

A

Fig. 1: Photos of Gmelina philippensis Cham.
A) The shrub (x0.03)
C) Obovate leaves (x0.25)
B) Young branch (x0.3)
D) 3-lobed (duckfoot) leaves (x0.4)

\section{MATERIALS AND METHODS}

\section{Plant material}

The aerial parts of Gmelina philippensis Cham. cultivated in The Experimental Station, Pharmacognosy Department, Faculty of Pharmacy, Assiut University, were collected during flowering in June 2015. It was supplied by Eng. Teres Labib (Director of El-Orman garden, Giza, Egypt), its identification was confirmed by Dr. Ahmed Farid (Associate Professor of Plant Taxonomy, Botany Department, Faculty of Science, Assiut University). The materials used for botanical study were taken from fresh leaves, stems and flowers or preserved samples in $70 \%$ ethanol containing 5\% glycerin. For the study of the powder, samples were air-dried separately, reduced to powder and kept for microscopical investigation. A voucher specimen was deposited at the herbarium of Pharmacognosy Department, Faculty of Pharmacy, Assiut University, Assiut, Egypt.
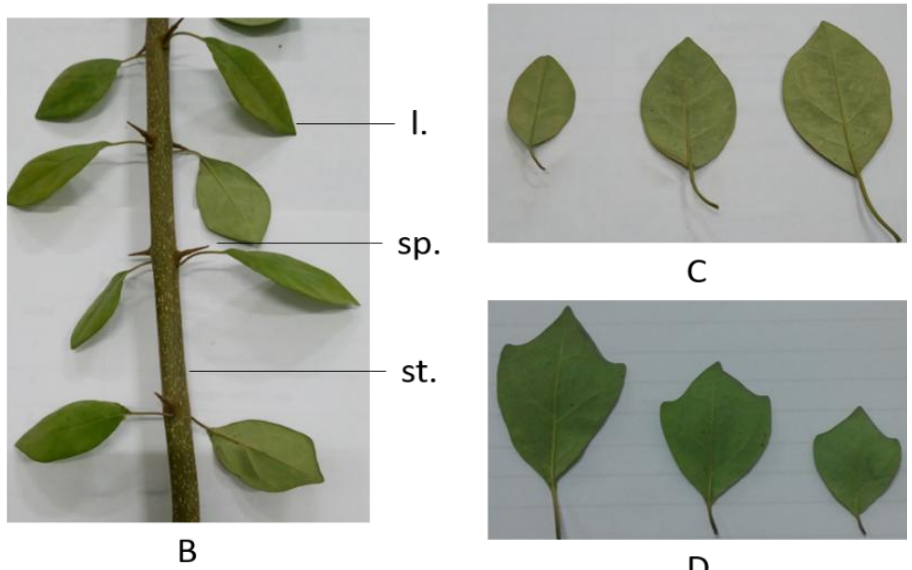

C

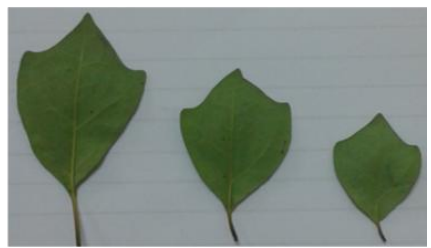

D

1., leaf; sp., spine; st., stem. 


\section{Dyes}

Safranin, light green, phloroglucinol, concentrated hydrochloric acid and iodine were used for staining the plant sections and the powder.

\section{Microscopic studies}

Surface preparations, transverse sections (T.S.) as well as powder of the leaves, stems and flowers were used for observation of various microscopic features. All microscopic investigations were done by using Microscope with camera, Leica ${ }^{\circledR}$ (Germany) and by Electron Microscope, JOEL, JSM-5400LV (Tokyo).

\section{RESULTS AND DISCUSSION}

\section{Macro- and micromorphological study of the leaves \\ Macromorphology}

The leaves are simple, petiolate, exstipulate, opposite decussate (Fig. 1B), varying in shape and size, being elliptic to obovate (Fig. 1C) and sometimes shallowly 3lobed (duckfoot) (Fig. 1D) measuring (3-7 cm) in length, $(2-3 \mathrm{~cm})$ in width, having rounded to acute apex, cuneate to decurrent base and entire margin. The surfaces are slightly hairy with upper dark green surface and a lower paler one. Venation is pinnately reticulate. The leaf is coriaceous in texture. The petiole is cylindrical to subcylindrical in shape, yellowish green in colour measuring about $(0.5-2.5 \mathrm{~cm})$ in length and about $(1-2 \mathrm{~mm})$ in diameter. The leaves have faint odour and slightly bitter taste.

\section{Micromorphology}

A transverse section in the lamina (Fig. 2A) appears more or less biconvex in outline showing prominent midrib on the lower surface than the upper, exhibiting a large median vascular strand, small bundles are observed in the lamina. It shows a dorsiventral mesophyll interrupted in the midrib region by one to three rows of collenchyma and spongy tissue. The vascular system at the midrib is formed of large, crescent-shaped collateral vascular bundle surrounded by an arc of pericyclic fibres. Upper epidermis shows few nonglandular hairs at the midrib region, while the lower one mostly shows glandular type.

\section{The Lamina}

\section{The upper epidermis}

The upper epidermis in transverse section (Fig. 3A\&B) consists of one row of square to subrectangular cells, covered with thin cuticle. In surface view (Fig. 2B) they appear polygonal, isodiametric to slightly elongated with straight anticlinal walls and covered with smooth cuticle. Those in the neural region (Fig. 2D) are axially elongated with straight anticlinal walls and covered with smooth cuticle. No stomata were observed. Few nonglandular bent hairs (Fig. 3A), consisting of two cells with short basal one, showing narrow lumina and covered with smooth cuticle, are observed especially in the midrib region.

\section{The lower epidermis}

In transverse section (Fig. 3A\&B), the lower epidermis consists of one row of square cells, covered with thin cuticle. In surface view (Fig. 2C), the cells are polygonal, mostly isodiametric with more sinuated anticlinal walls and covered with smooth cuticle. Numerous anomocytic stomata are observed. Sunken glandular hairs consisting of unicellular stalk and a four- or eight-celled head, are observed and confirmed by electron microscope (E.M.) examination of the surface (Fig. 2E).

\section{The mesophyll}

The mesophyll is dorsiventral (Fig. 3B), differentiated into an incontinuous upper palisade layer and spongy tissue. The palisade is formed of one row of columnar cylindrical thin-walled cells containing chloroplasts. The spongy tissue is formed of about four rows of more or less rounded to ovoid or irregular thinwalled parenchyma cells containing chloroplasts with wide intercellular spaces. Small vascular bundles are embedded within the spongy tissue.

\section{The midrib \\ The cortical tissue}

The cortical tissue in the midrib region (Fig. 3A) is represented by upper and lower subepidermal zones consisting of three rows of nearly rounded cellulosic collenchymatous cells. The upper collenchyma is followed by about three rows of thin-walled rounded to oval 


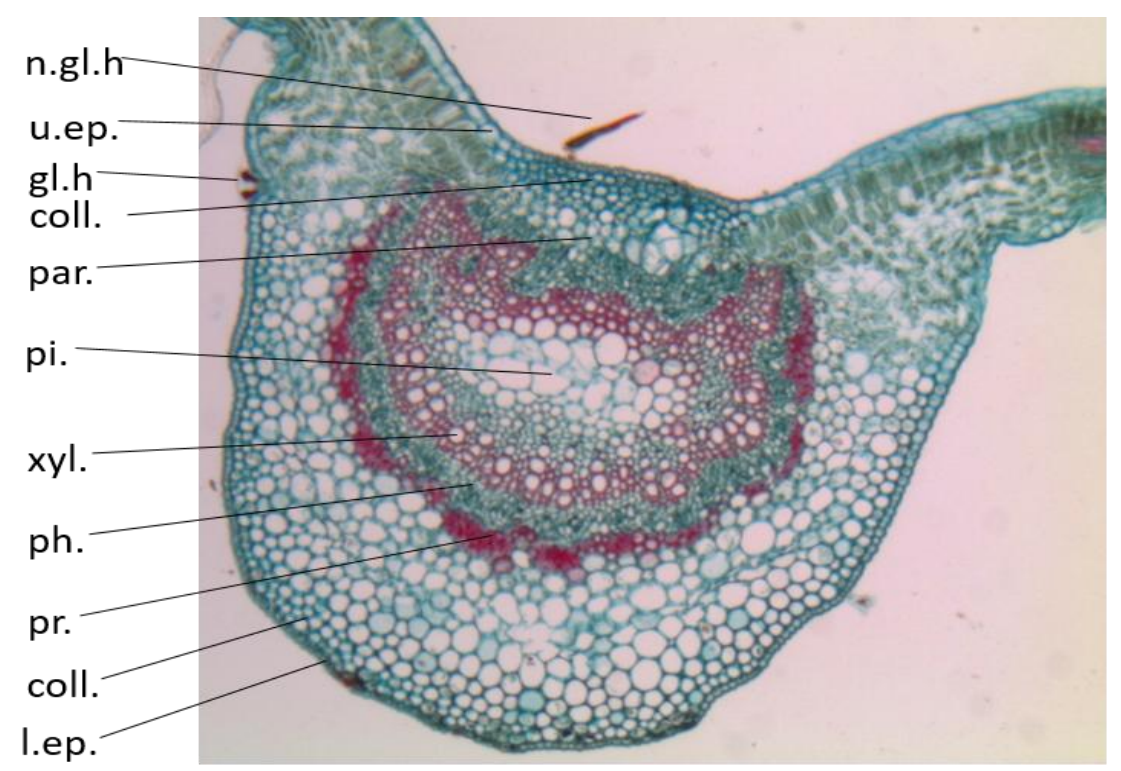

A

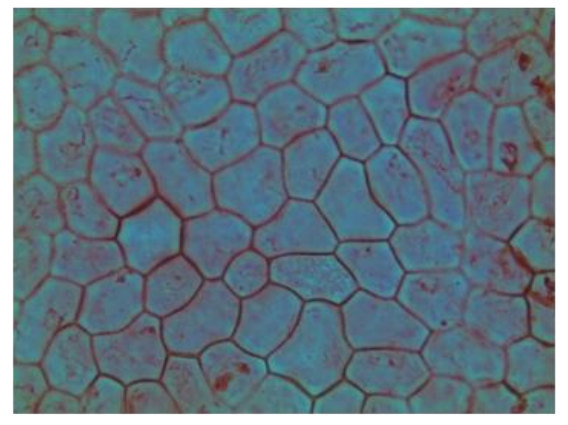

B

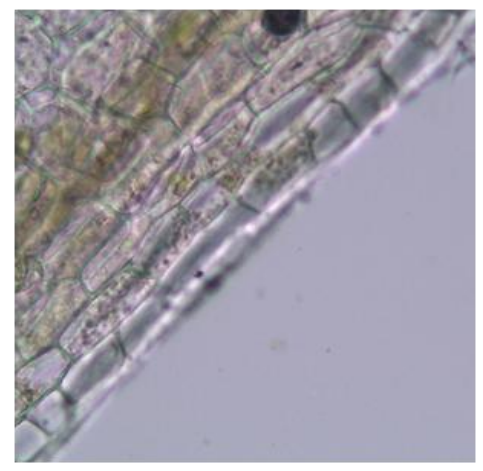

D

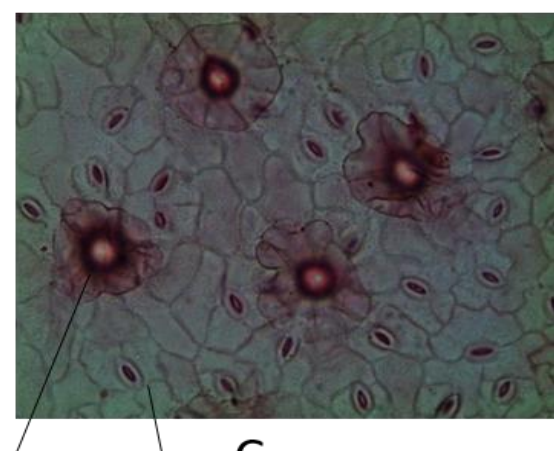

C

gl.h. st.

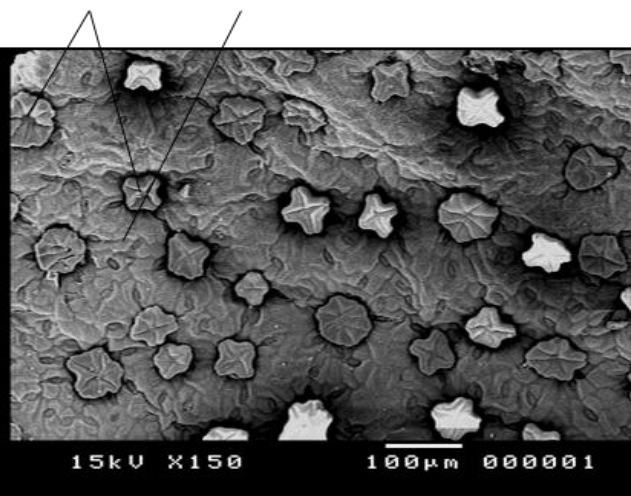

E

Fig. 2: Photos of the microscopical study of Gmelina philippensis Cham. leaves.

A) Diagrammatic T.S. in the leaf of Gmelina philippensis Cham. (x40)

Surface preparations of the leaf:

B) Upper epidermal cells of the leaf (x200)

C) Lower epidermal cells of the leaf (x200)

D) Neural upper epidermal cells (x200)

E) Lower epidermal cells of the leaf (E.M.)

coll., collenchyma; gl.h., glandular hair; l.ep., lower epidermis; n.gl.h., non-glandular hair; par., parenchyma; ph., phloem; pi., pith; pr., pericycle; st., stomata; u.ep., upper epidermis; xyl., xylem. 


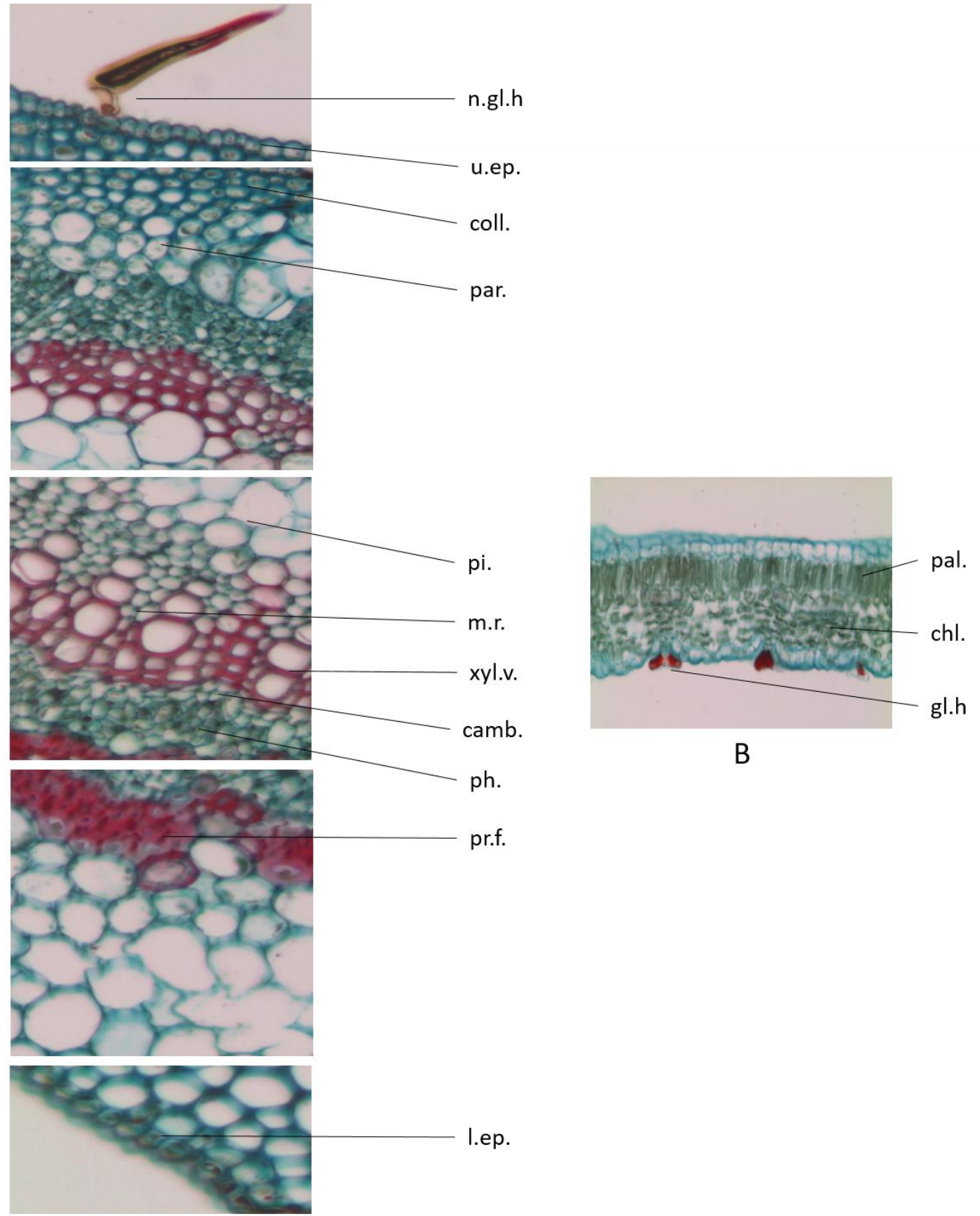

A

Fig. 3: Photos of the detailed T.S. in the leaf of Gmelina philippensis Cham.

A) Detailed T.S. in the midrib region (x100)

B) Detailed T.S. in the lamina (x100)

camb., cambium; chl., chlorenchyma; coll., collenchyma; gl.h., glandular hair; l.ep., lower epidermis; m.r., medullary ray; n.gl.h., non-glandular hair; pal., palisade; par., parenchyma; ph., phloem; pi., pith; pr.f., pericyclic fibres; u.ep., upper epidermis; xyl.v., xylem vessel. 
parenchymatous cells while the lower one is followed by about seven rows of larger parenchymatous cells. No starch or calcium oxalate crystals are observed.

\section{The pericycle}

It consists of crescent-shaped zone around the vascular tissues (Fig. 2A) and represented by groups of lignified fibers, moderately thickwalled, with wide lumina, acute apices and dentate margins (Fig. 5E).

\section{The vascular system}

It is represented by several collateral vascular bundles of variable sizes the main is in the midrib region (Fig. 3A). It is crescentshaped with additional inverted strands linking the two ends of the crescent and enclosing a central pith. Each vascular bundle is formed of xylem and phloem surrounded by incomplete ring of pericyclic fibres.

The phloem is formed of small, thinwalled cellulosic cells, hardly differentiated into sieve tubes, companion cells, and phloem parenchyma. The cambium is very narrow consisting of two to three rows of thin walled, subrectangular, tangentially elongated cellulosic cells. The xylem is formed of radial rows of lignified vessels along with tracheids, tracheidal vessels, wood fibres and wood parenchyma. The vessels are mostly of reticulated or scalariform thickening (Fig. 5F). The wood fibres are fusiform, thick-walled with narrow lumina, acute apices, some of them have forked ends (Fig. 5G). Tracheids (Fig. $5 \mathrm{H}$ ), are rectangular in shape with pitted lignified walls. The xylem is traversed by lignified rectangular to subrectangular wood parenchyma and polygonal uni- to multiseriate medullary rays which are lignified in the xylem region and non-lignified in the phloem region. The vascular pith is parenchymatous with narrow intercellular spaces.

\section{Micromorphology of the petiole}

A transverse section in the petiole (Fig. 4A) appears shield-shaped. It is surrounded by an outer epidermis followed by a wide parenchymatous cortex enclosing a large median crescent-shaped vascular bundle, accompanied by two smaller accessory ones towards the wings.

\section{The epidermis}

In transverse section (Fig. 4B), the epidermis is formed of one row of square to subrectangular cells, covered with thin cuticle. In surface view (Fig. 4C) the epidermal cells are polygonal, nearly isodiametric with thick straight anticlinal walls and covered with smooth cuticle. Few non-glandular bicellular bent hairs similar to those of the leaf are observed. Stomata are almost absent.

\section{The cortical tissue}

The cortical tissue (Fig. 4B), is formed of two to three rows of rounded collenchyma cells with thick cellulosic walls followed by about eight rows of thin-walled parenchyma cells with narrow intercellular spaces. The cells are increasing gradually in size. No starch or calcium oxalate crystals are observed.

\section{The pericycle}

The pericycle (Fig. 4B), consists of one to two rows of small rounded to polygonal parenchymatous cells.

\section{The vascular system}

It is represented by crescent-shaped collateral vascular strands consisting of an upper radiating arc of xylem followed by a lower arc of phloem, in addition to two small vascular bundles in the cortical tissue towards the wings (Fig. 4A).

The phloem is formed of several rows of small, thin-walled soft cellulosic elements. The cambium is hardly distinguishable. The xylem consists of radial rows of lignified vessels and separated by uni- to bi-seriate polygonal to subrectangular non-lignified medullary rays.

\section{The powder of the leaf}

The powdered leaves are green in colour with faint odour and bitter taste. The powder is characterized microscopically (Fig. 5) by the following fragments:

1- Fragments from the upper epidermal cells, that appear polygonal with straight anticlinal walls and covered with smooth cuticle.

2- Fragments from the lower epidermal cells, which are polygonal with sinuated anticlinal walls and covered with smooth cuticle, showing anomocytic stomata and glandular hairs. 

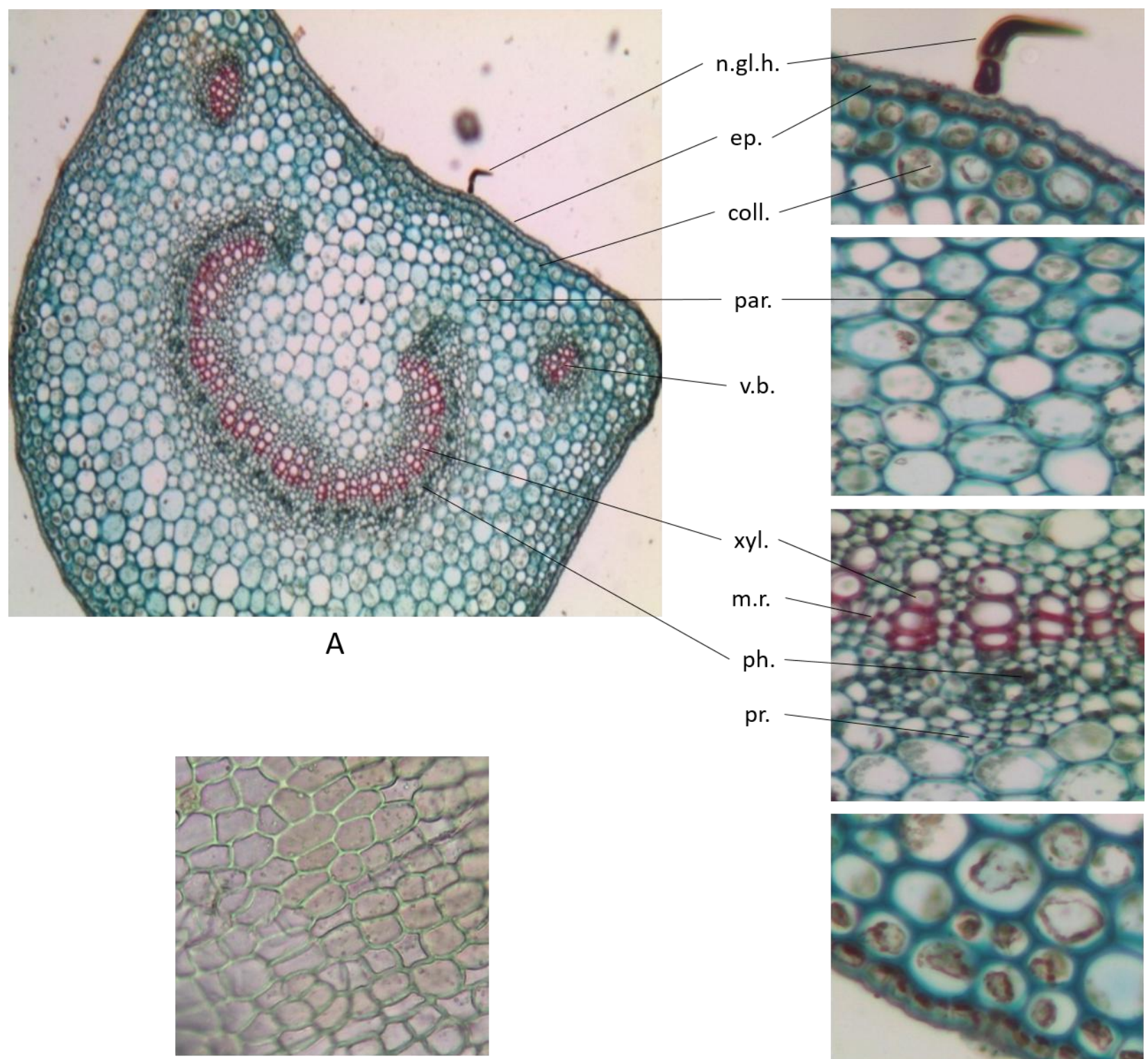

C

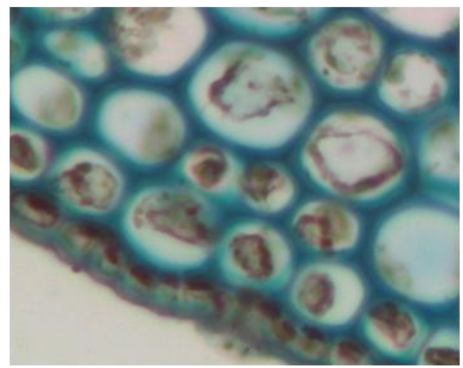

B

Fig. 4: Photos of the microscopical study in Gmelina philippensis Cham. petiole.

A) Diagrammatic T.S. in the petiole ( $x 40)$

B) Detailed T.S. in the petiole (x200)

C) Surface preparation of the petiole (x200)

coll., collenchyma; ep., epidermis; m.r., medullary ray; n.gl.h., non-glandular hair; par., parenchyma; ph., phloem; pr., pericycle; v.b., vascular bundle; xyl., xylem. 


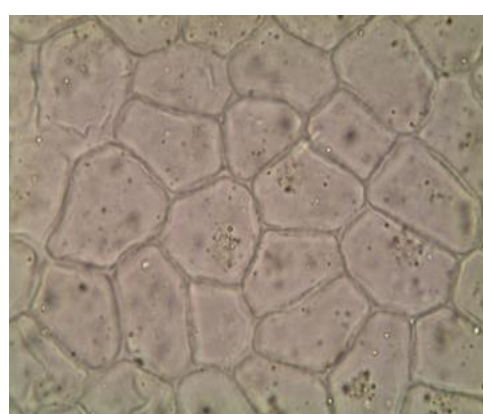

A

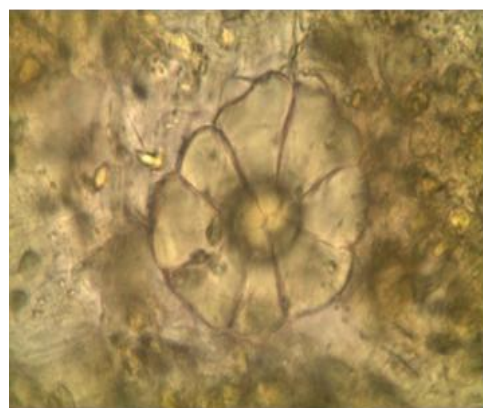

D

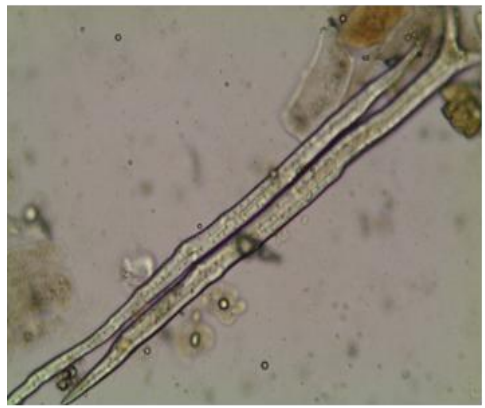

G

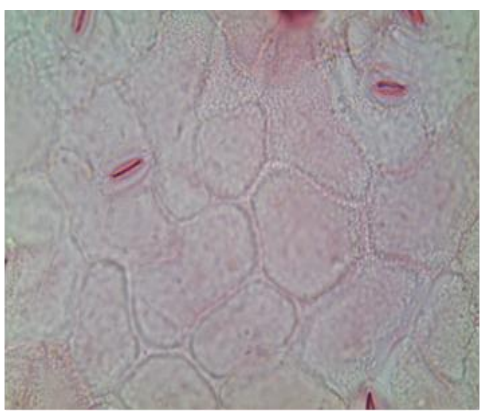

B

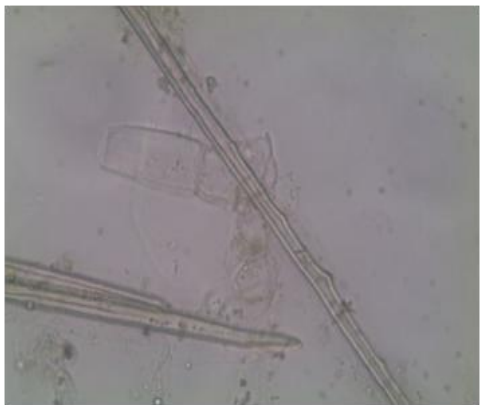

$E$

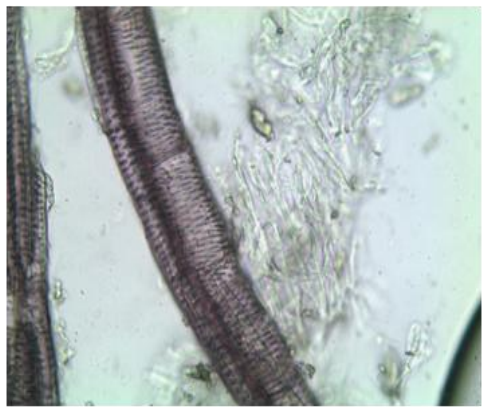

$\mathrm{H}$

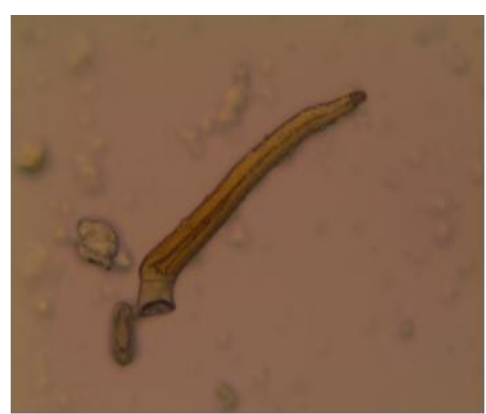

C

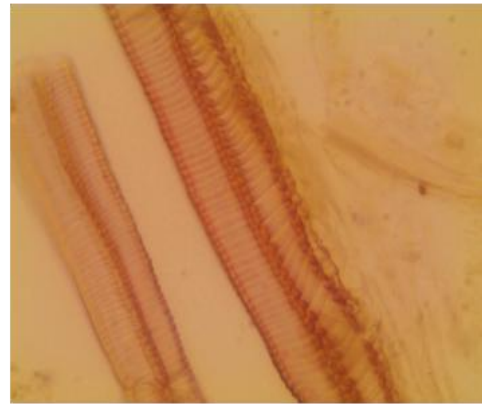

$\mathrm{F}$

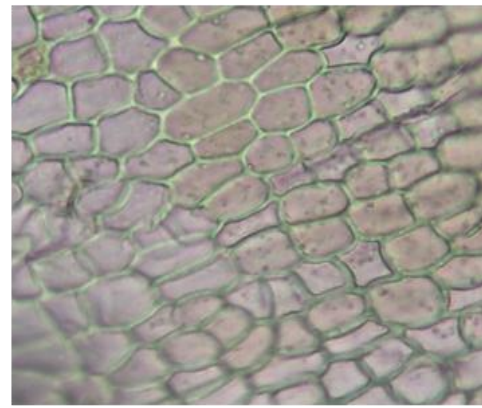

I

Fig. 5: Photos of the microscopical examination of the powdered Gmelina philippensis leaves.

A) Fragment of the upper epidermal cells (x200)

B) Fragment of the lower epidermal cells (x200)

C) Non-glandular bent hair (x200)

D) Glandular hair (x200)

E) Pericyclic fibres (x100)

F) Xylem vessels (x100)

G) Wood fibres (x100)

H) Tracheids and tracheidal vessels (x100)

I) Fragment of the epidermal cells of the petiole (x200) 
3- Non-glandular uniseriate bicellular bent hairs covered with smooth cuticle and glandular hairs having unicellular stalk and four- or eight-celled head.

4- Dentate lignified pericyclic fibres with thick walls, wide lumina and acute apices.

5- Lignified xylem vessels with reticulated or scalariform thickening.

6- Fusiform wood fibres with thick walls, narrow lumina and acute apices. Some have forked ends.

7- Tracheids and tracheidal vessels which are rectangular in shape with pitted lignified walls.

8- Fragments from the epidermal cells of the petiole, which are polygonal with straight anticlinal walls and covered with smooth cuticle.

\section{Macro- and micromorphological study of the stem Macromorphology}

The main stem (Fig. 1B) is woody, nearly cylindrical in shape, quadrangular at the terminal parts, reaching about $(2-3.5 \mathrm{~m})$ in height and measuring $(0.6-3 \mathrm{~cm})$ in diameter with lateral branches measuring $(0.2-0.5 \mathrm{~cm})$ in diameter and carry axillary spines measuring $(0.3-2.5 \mathrm{~cm})$ in length. The stem is monopodially branched with short internodes, terminal parts are green in colour while the lower ones are greenish brown with rough surface, smooth fracture and bears numerous lenticels. The stem is nearly odourless with slightly bitter taste.

\section{Micromorphology of the young stem}

A transverse section in young stem (Fig. 6A), is somewhat quadrangular in outline. It consists of an outer epidermis covered with thin cuticle and carrying non-glandular trichomes. The epidermis is followed by narrow cortex consisting of nearly four rows of collenchyma followed by parenchymatous cells. The endodermis is not distinguished and the pericycle is parenchymatous followed by collateral vascular bundle surrounding a wide region of pith.

\section{The epidermis}

In transverse section (Fig. 6B), it consists of one row of nearly square cells covered with thin cuticle. In surface view (Fig. 6C), they appear polygonal, nearly isodiametric in shape with straight anticlinal walls and covered with smooth cuticle. The epidermal cells carry nonglandular bent hairs consisting of two cells with short basal one and covered with smooth cuticle. No stomata are observed.

\section{The cortex}

The cortex (Fig. 6B) consists of about four rows of rounded collenchyma cells followed by four rows of parenchymatous cells, while the endodermis is not distinguished. No starch or calcium oxalate crystals are observed.

\section{The pericycle}

The pericycle (Fig. 6B) consists of few rows of nearly rounded parenchyma cells.

\section{The vascular system}

The vascular system (Fig. 6B) is represented by collateral bundle. The phloem consists of thin-walled cellulosic parenchymatous cells. The cambium is formed of three rows of thin walled, subrectangular, tangentially elongated and radially arranged cellulosic cells. The xylem consists of narrow zone of radially arranged elements of xylem vessels, wood fibers and wood parenchyma. The vessels are lignified and separated by bi- to multiseriate nonlignified medullary rays.

The pith is a wide central zone consisting of rounded parenchymatous cells increasing in size towards the center. No starch or calcium oxalate crystals are observed.

\section{Micromorphology of the moderate-aged stem}

A transverse section in the stem (Fig. 7A) is somewhat circular in outline. It consists of an outer epidermis covered with thin cuticle and carrying non-glandular bent hairs. The epidermal cells are followed by narrow cortex consisting of collenchyma and parenchyma cells. The endodermis is indistinguishable, the pericycle is formed of continuous ring of fibres interrupted by few sclerenchymatous cells and followed by collateral vascular bundle surrounding a wide hollow pith. The older parts of stem are covered with few rows of brownish cork cells. 


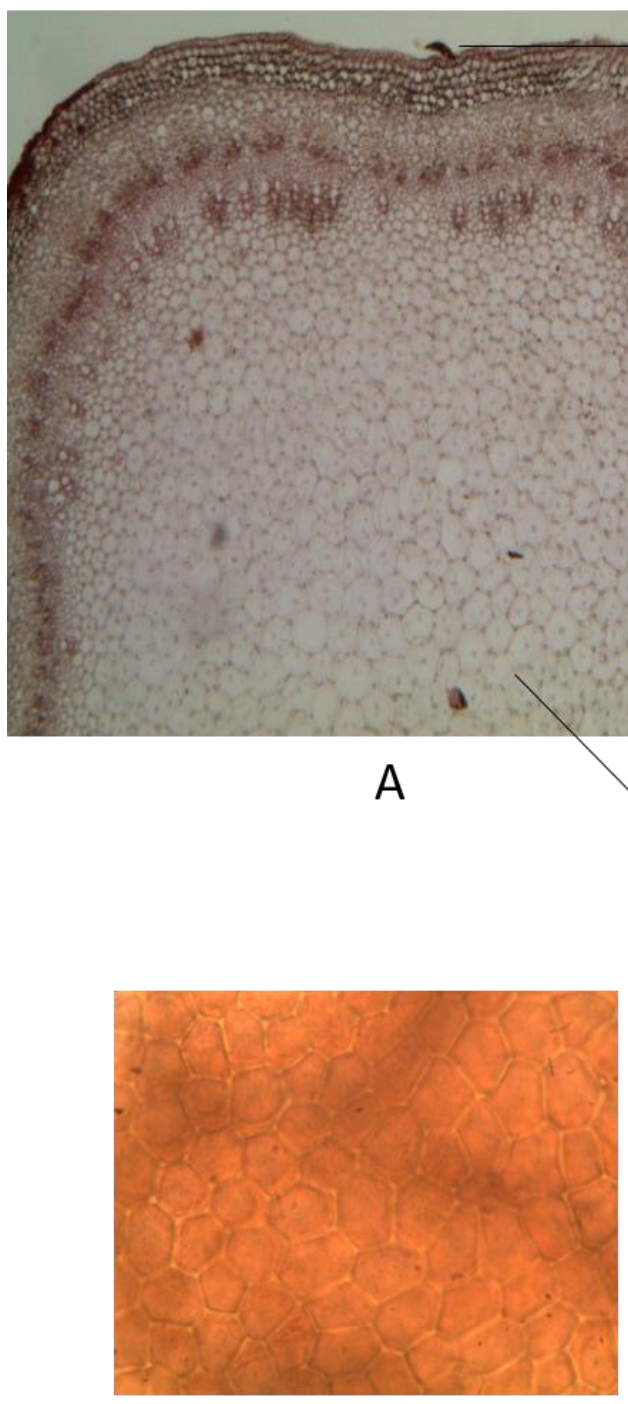

C n.gl.h.

ep.

coll.

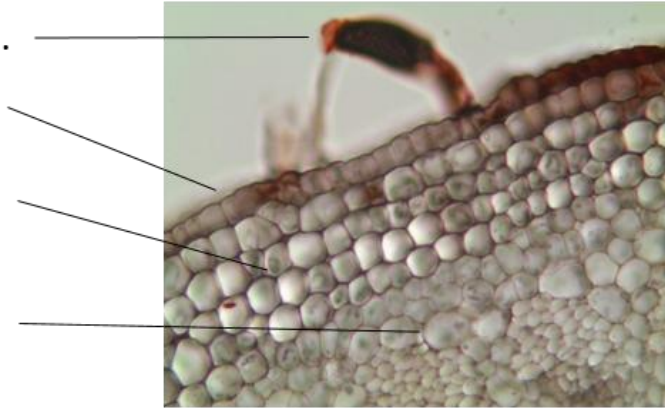

pr.

ph.

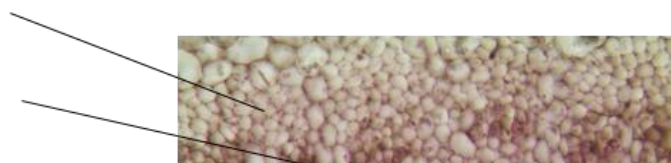

camb.

xyl.

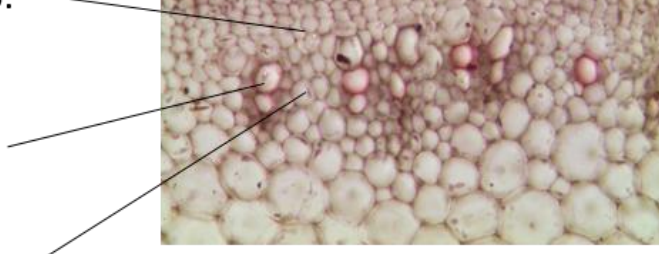

m.r.

pi.

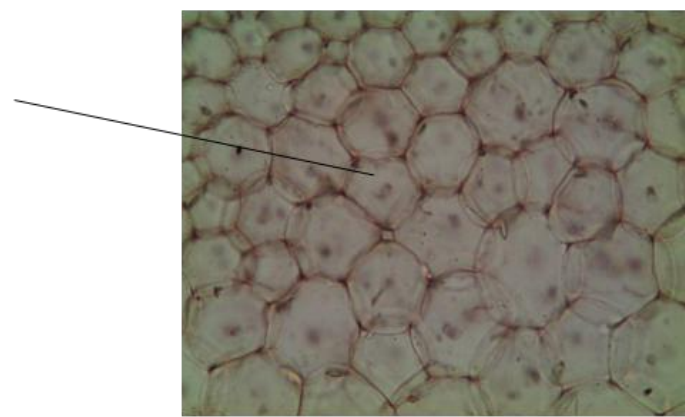

B

Fig. 6: Photos of the microscopical study of Gmelina philippensis Cham. young stem.

A) Diagrammatic T.S. of the young stem (x40)

B) Detailed T.S. of the young stem (x200)

C) Surface preparation of the young stem (x200)

camb., cambium; coll., collenchyma; ep., epidermis; m.r., medullary ray; n.gl.h., non-glandular hair; par., parenchyma; ph., phloem; pi., pith; pr., pericycle; xyl., xylem. 


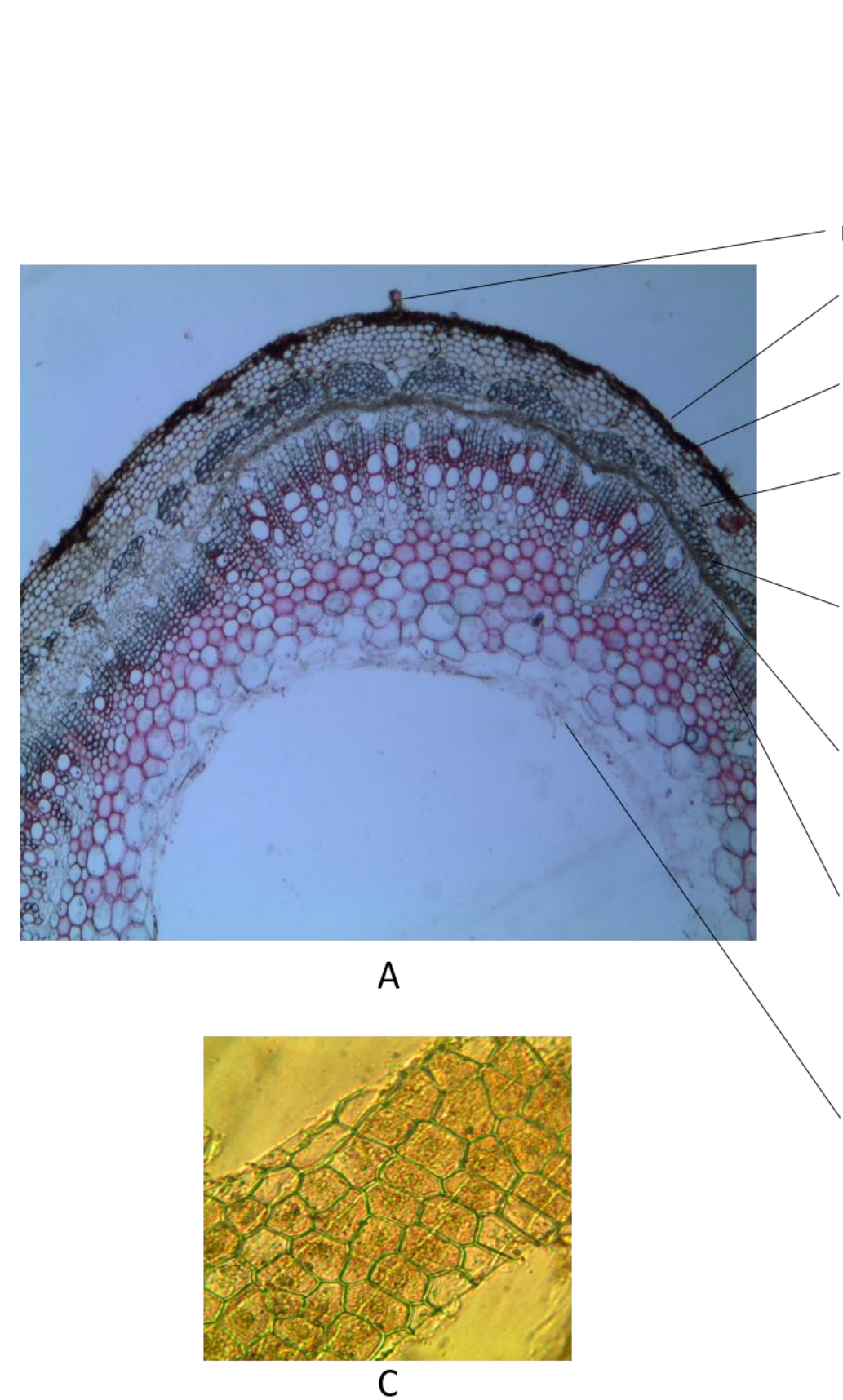

n.gl.h.
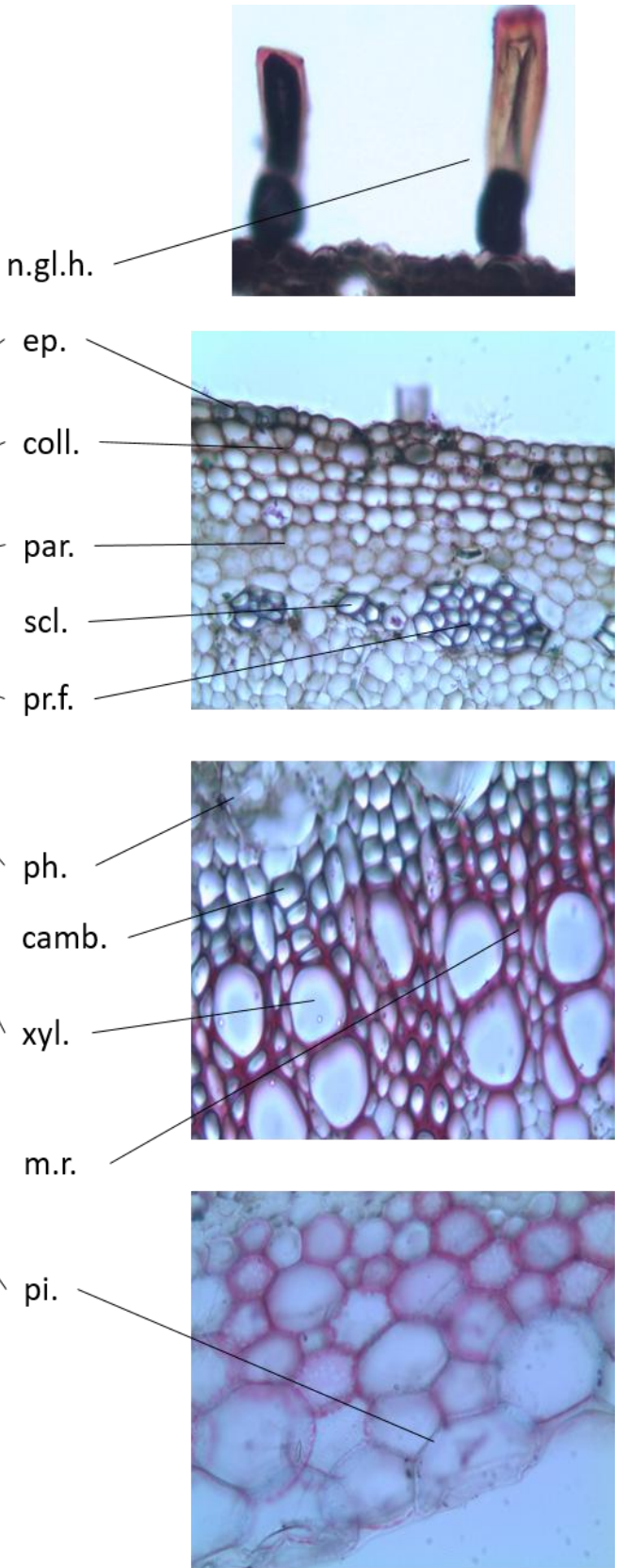

B

Fig. 7: Photos of the microscopical study of Gmelina philippensis Cham. moderate-aged stem.

A) Diagrammatic T.S. in the moderate-aged stem (x40)

B) Detailed T.S. of the moderate-aged stem (x200)

C) Surface preparation of the moderate-aged stem (x200)

camb., cambium; coll., collenchyma; ep., epidermis; m.r., medullary ray; n.gl.h., non-glandular hair; par., parenchyma; ph., phloem; pi., pith; pr.f., pericyclic fibres; scl., sclereids; xyl., xylem. 


\section{The epidermis}

In transverse section (Fig. 7B), it consists of one row of nearly square cells covered with thin cuticle. In surface view (Fig. 7C), they appear polygonal, nearly isodiametric in shape and covered with smooth cuticle. The cells carry non-glandular bent hairs as those of the young stem. No stomata are observed.

\section{The cortex}

The cortex (Fig. 7B), consists of about three rows of rounded collenchyma cells followed by about three rows of parenchymatous cells with narrow intercellular spaces. The endodermis is indistinguishable. No starch or calcium oxalate are observed.

\section{The pericycle}

The pericycle (Fig. 7B), is formed of more or less continuous ring of fibres interrupted by few sclerenchymatous cells. The fibres are fusiform with thick pitted lignified walls, narrow lumina, blunt to rounded apices and dentate margins (Fig. 8C). Few sclereids, which are nearly square to rectangular in shape with thick pitted lignified walls and narrow lumina (Fig. 8 D).

\section{The vascular system}

The vascular system (Fig. 7B), is represented by a continuous ring of phloem, cambium and xylem. The phloem is formed of thin-walled cellulosic parenchymatous elements and separated from the xylem by cambial zone formed of nearly three rows of thin walled, subrectangular, tangentially elongated and radially arranged cellulosic cells. The xylem consists of narrow zone of radially arranged elements consisting of reticulated and pitted lignified vessels. Wood fibers (Fig. 8F), are fusiform in shape, lignified with comparatively wide lumina and blunt to acute apices. Tracheids (Fig. 8G), are subrectangular in shape, with thick pitted lignified walls, in addition to lignified wood parenchyma cells (Fig. $8 \mathrm{H}$ ). The vessels are traversed by bi- to multiseriate lignified medullary rays consisting of pitted rectangular cells (Fig. 8I).

The pith is a wide central zone and mostly hollow. The periphery of the pith consists of pitted lignified nearly rounded parenchyma cells (Fig. 8J).

\section{The powder of the stem}

The powdered stem is yellowish brown in colour with faint odour and slightly bitter taste. Microscopically it is characterized by the following fragments (Fig. 8):

1- Fragments of the epidermal cells of young and moderate-aged stems, both in surface view appear polygonal with straight anticlinal walls and covered with smooth cuticle.

2- Non-glandular uniseriate bicellular bent hairs covered with smooth cuticle.

3- Dentate lignified pericyclic fibres with thick walls, narrow lumina and blunt apices.

4- Sclereids that are square to rectangular in shape with thick pitted lignified walls and narrow lumina.

5- Pitted and reticulated lignified xylem vessels.

6- Fusiform wood fibres with thick lignified wide lumina and blunt to acute apices.

7- Tracheids that are subrectangular in shape with thick pitted lignified walls.

8- Lignified wood parenchyma, medullary rays and pitted parenchyma of the pith.

9- Fragments of cork cells from older stems, that appear polygonal, square to subrectangular in shape with thick lignified walls.

\section{Macro- and micromorphological study of the inflorescence \\ Macromorphology}

The inflorescence (Fig. 9A) is terminal, axillary, panicle reaching $(5-10-15 \mathrm{~cm})$ in length and produces yellow flowers from a long tube-shaped structure comprised of overlapping persistent leafy bracteoles. The rachis (Fig. 9B), is cylindrical, brownish in colour measuring $(5-10-15 \mathrm{~cm})$ in length, $(1-3$ $\mathrm{mm}$ ) in diameter, bearing pairs of bright yellow-coloured flowers at each node in opposite decussate arrangement and the terminal ones being the largest with slight aromatic odour and taste.

Each flower arises at the axil of the bracteole. The flowers are complete, sessile, hermaphrodite, zygomorphic, hypogenous with floral formula: \%, $\%, \mathbf{K}_{(5)}, \mathbf{C}_{(4)}, \mathbf{A}_{2+2}, \underline{\mathbf{G}(2)}$.

The leafy bracteoles (Fig. 9C) are ovoid to rhomboidal in shape, green with purplish tinge outside, pale green with pinkish tinge inside, 


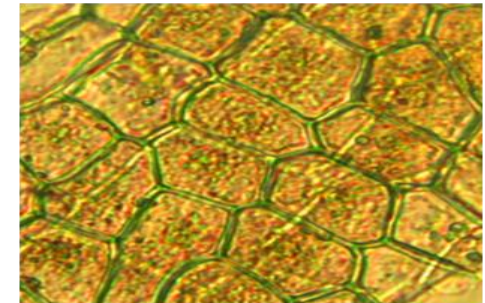

A

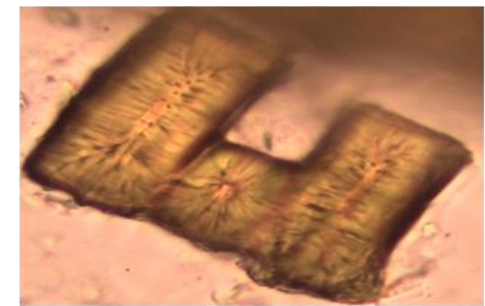

D

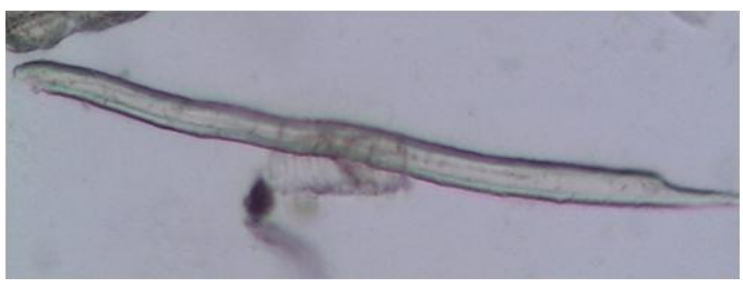

F

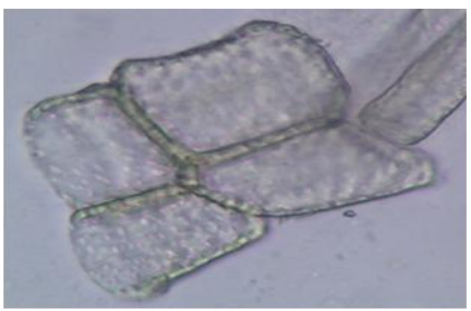

$\mathrm{H}$

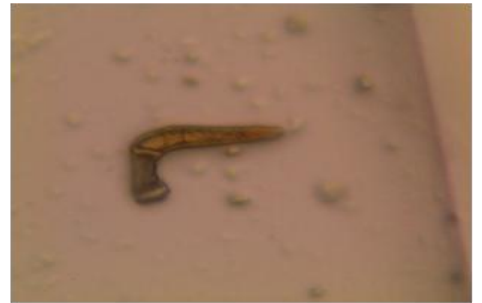

B

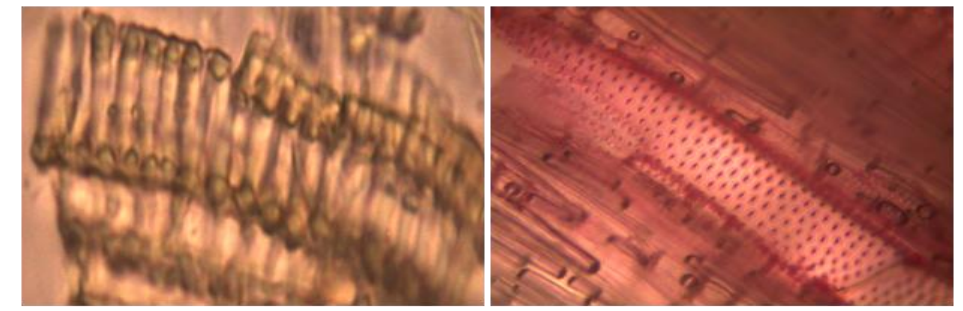

E

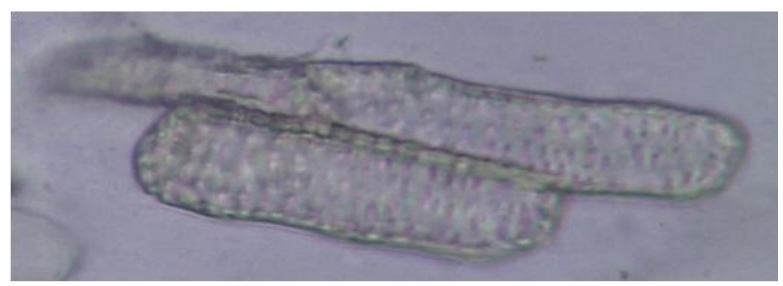

G

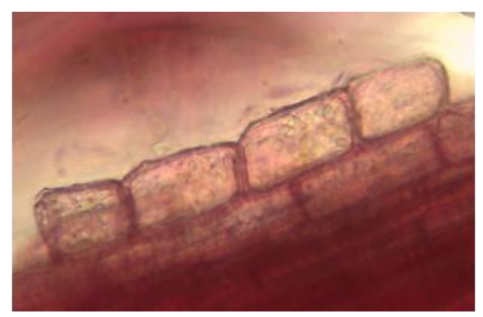

I

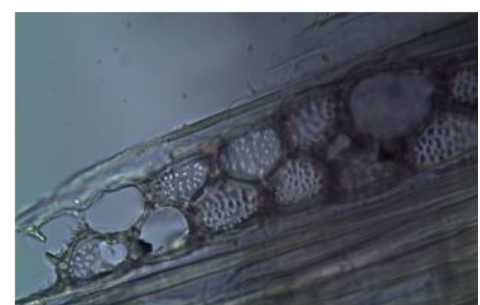

J

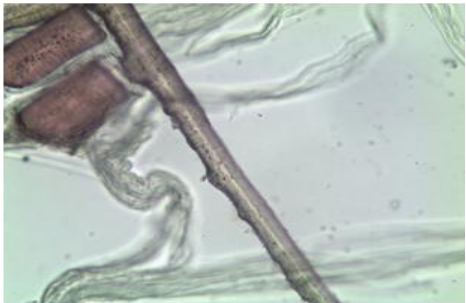

C

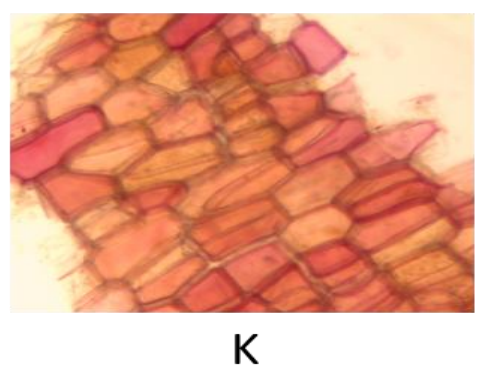




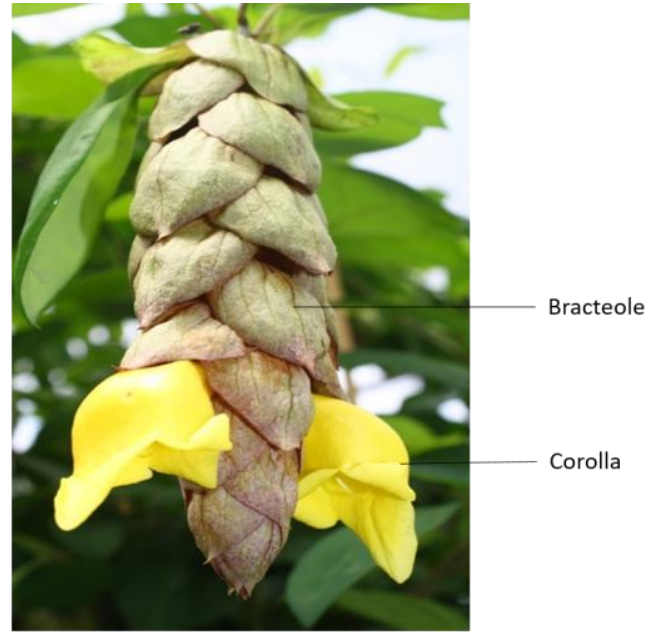

A

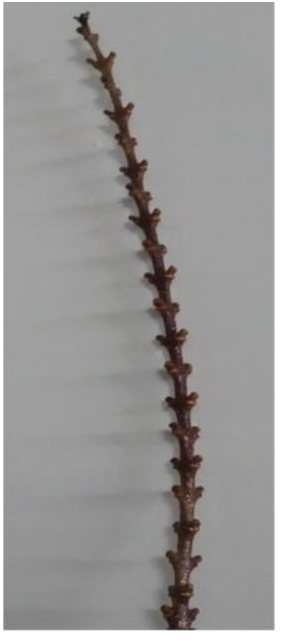

B

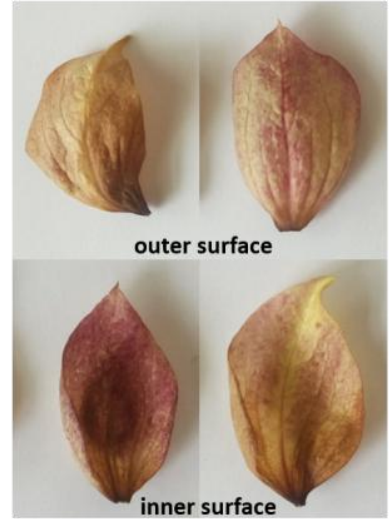

C

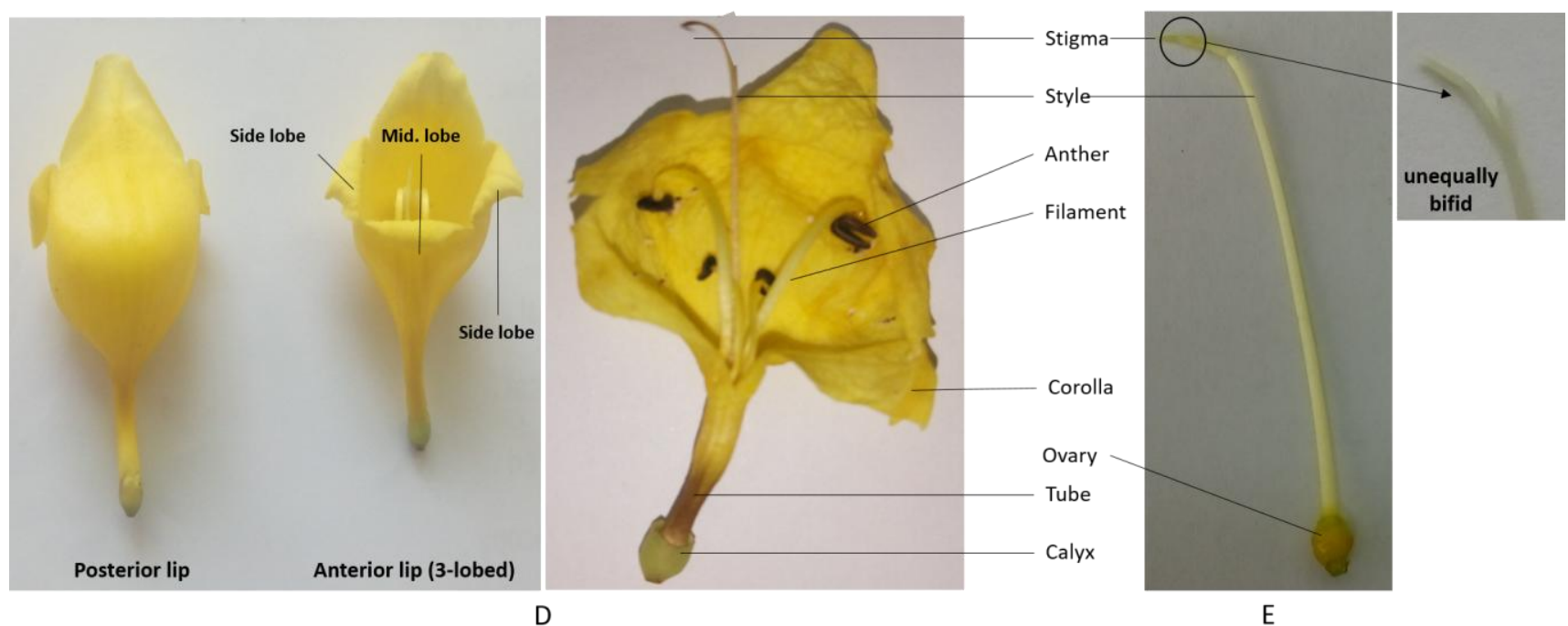

Fig. 9: Photos of Gmelina philippensis Cham. inflorescence and flower.

A) The inflorescence ( $\mathrm{x} 0.6)$

B) The rachis $(\mathrm{x} 0.5)$

C) The bracteoles, inner and outer surfaces (x0.5)

D) The flower "parrot's peak" (x2)

E) The gynoecium (x2)

sessile and persistent. They have entire margin, acute to rounded apices, hairy surface, membranous texture and measuring $(2-5 \mathrm{~cm})$ in length and $(2-3 \mathrm{~cm})$ in width.

The calyx (Fig. 9D) is gamosepalous consisting of tubular, five united sepals each is ovoid in shape with rounded apex, pale yellowish green in colour, measuring $(3-5 \mathrm{~mm})$ in length and $(2-3 \mathrm{~mm})$ in width. The outer surface is pubescent with about three discoid nectary glands in contrast to the inner surface.

The corolla (Fig. 9D) is gamopetalous, tubular in shape, measuring $(2.5-5 \mathrm{~cm})$ in length, $(1-2 \mathrm{~cm})$ in diameter, consisting of four bright yellow united petals with a prominent anterior lip and all have acute to rounded apices. The anterior lip is 3-lobed, mid-lobe measures $(6.5-12 \mathrm{~mm})$ in length and $(3-9 \mathrm{~mm})$ in width, side lobes measure $(6-8 \mathrm{~mm})$ in length and (3.5-7 mm) in width, posterior lip is 1-lobed, measuring $(4.5-15 \mathrm{~mm})$ in length and $(6-14 \mathrm{~mm})$ in width, corolla tube measures (1$1.6 \mathrm{~cm}$ ) in length. The outer surface is pubescent while the inner surface is glabrous. Corolla is slightly fragrant. 
The androecium (Fig. 9D): The flower is tetrandrous, possessing four, free, didynamous, epipetalous yellow stamens, inserted half-way at apex of the corolla tube and arranged in one whorl of two long filaments measuring (1.2-2.2 $\mathrm{cm}$ ) in length and two shorter ones measuring $(1-1.3 \mathrm{~cm})$ in length. The anthers are bilobed, dorsifixed, anterior pair is longer, pale yellow when fresh, brownish upon drying, each attached at its base to the tip of the filament and measuring about $(3 \mathrm{~mm})$ in length.

The gynoecium (Fig. 9E): The ovary is obovoid, bicarpellary, tetralocular, syncarpous, sessile, glabrous, pale green to yellowish green in colour measuring (4-5 mm) in length and (2$3 \mathrm{~mm}$ ) in width. It carries at the top a slender, filiform, pale yellow glabrous style measuring $(2-4 \mathrm{~cm})$ in length and a yellow unequally bifid stigma.

\section{Micromorphology of the flower (surface preparation of the floral parts) Micromorphology of the calyx}

The upper epidermis (inner surface) (Fig. 10A): In surface view it consists of polygonal, subrectangular cells with slightly thick straight anticlinal walls and covered with smooth cuticle. No stomata are observed.

The lower epidermis (outer surface) (Fig. 10B): In surface view it consists of polygonal, nearly isodiametric cells with slightly thick straight anticlinal walls and covered with smooth. The cells carry numerous nonglandular bicellular bent hairs covered with warty cuticle and few glandular four- to eightcelled head hairs. Stomata of the anomocytic type are observed.

\section{Micromorphology of the corolla}

The upper epidermis (inner surface) (Fig. 10C,D\&E): In surface view it consists of polygonal cells that show distinct variation in shape and size according to their position. At the apical and middle regions, they are polygonal in shape with slightly wavy anticlinal walls at the apical region (Fig. 10C) and covered with papillosed cuticle. In the middle, they are covered with slightly papillosed cuticle (Figs. 10D,11A\&B) and carry glandular hairs consisting of unicellular stalk and bicellular head, that were confirmed by the electron microscope (Fig. 11C). At the basal region (the tube) (Fig. 10E) the epidermal cells are polygonal, subrectangular and covered with smooth cuticle. No stomata or hairs are observed.

The lower epidermis (outer surface) (Fig. $10 \mathrm{~F}, \mathrm{G} \& \mathrm{H})$ : In surface view it consists of polygonal cells that vary in shape and size at different regions. At the apical region (Fig. 10F), they are polygonal, nearly isodiametric with wavy anticlinal walls, covered with striated cuticle and carry glandular hairs consisting of unicellular stalk and four-celled head, also unicellular stalk and bicellular head, in addition to non-glandular bent hairs covered with warty cuticle. While the cells at the middle region (Figs. 10G\&11D) are polygonal, slightly elongated with nearly straight anticlinal walls and covered with striated cuticle. The epidermal cells carry nonglandular bicellular uniseriate bent hairs covered with warty cuticle (Fig. 13E) along with glandular four-celled head hairs (Fig. 13F). Few stomata of the anomocytic type are observed. Epidermal cells at the basal region (the tube) (Fig. 10H) are polygonal, subrectangular in shape and covered with smooth cuticle. No stomata or hairs are observed.

\section{Micromorphology of the androecium}

The epidermal cells of the filament in surface view vary in shape and size at different positions (Fig. 12A,B\&C). They are polygonal, nearly isodiametric at the apical region, subrectangular at the middle and basal parts with thick walls and covered with striated cuticle.

The epidermis of the anther in surface view (Fig. 12D), is formed of polygonal papillosed cells with nearly straight anticlinal walls and covered with striated cuticle. Fibrous layer of anther (Fig. 12E), shows beaded walls and transverse bar-like thickening.

The pollen grains (Fig. 12F) are prolate in shape, tricolpate with bireticulate exine, which was confirmed by electron microscope (Fig. $12 \mathrm{G} \& \mathrm{H})$. When mature they are yellow in colour.

\section{Micromorphology of the gynoecium}

The outer epidermal cells of the ovary in surface view (Fig. 12I) are polygonal, nearly isodiametric with straight anticlinal walls and covered with smooth cuticle. Stomata of the anomocytic type which are nearly circular in shape are observed. 


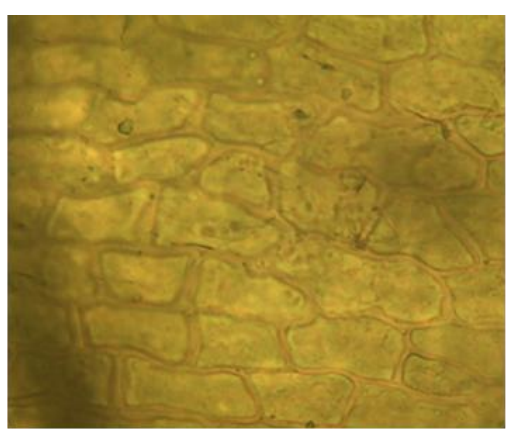

A

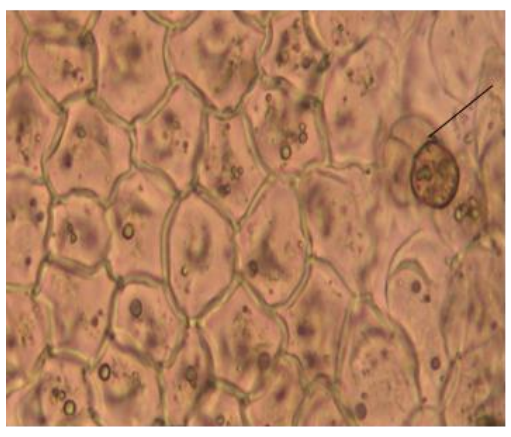

C

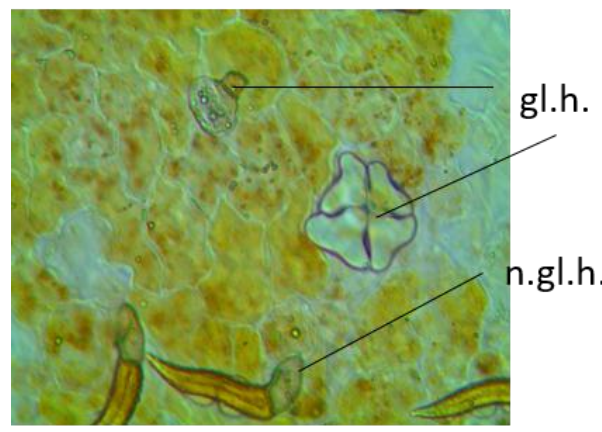

$\mathrm{F}$
St.

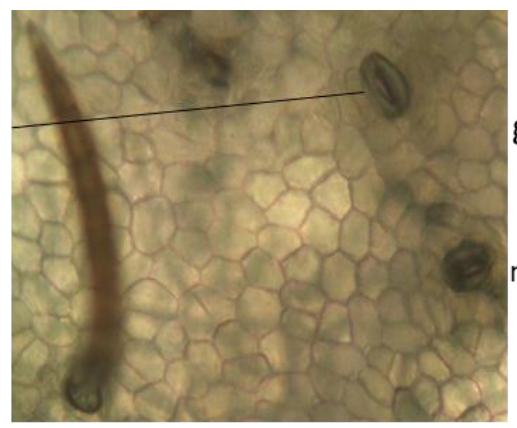

gl.h.

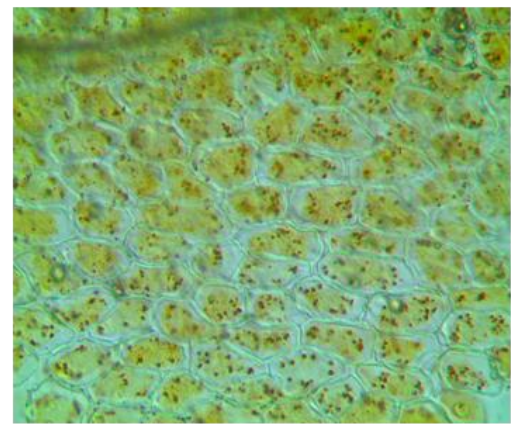

D

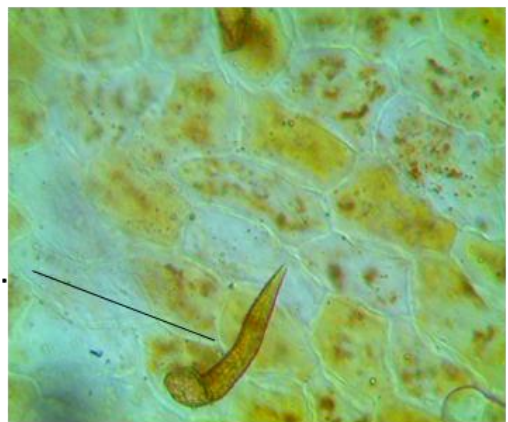

G

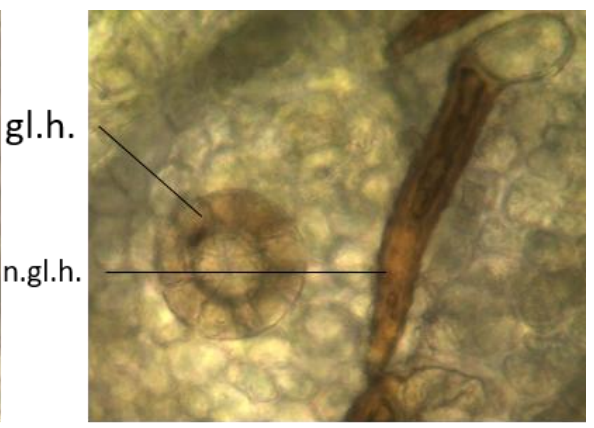

B

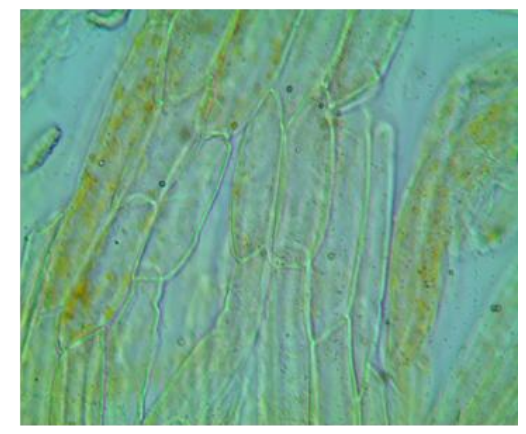

$\mathrm{E}$

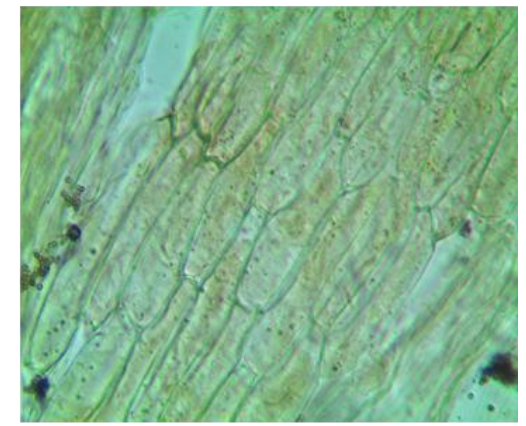

$\mathrm{H}$

Fig. 10: Photos of the microscopical examination of the calyx and corolla of Gmelina philippensis Cham. (x200)

A) Upper epidermis of the calyx

B) Lower epidermis of the calyx

C) Upper epidermis of the corolla (apical region)

D) Upper epidermis of the corolla (middle region)

E) Upper epidermis of the corolla (basal region / tube)

F) Lower epidermis of the corolla (apical region)

$\mathrm{G})$ Lower epidermis of the corolla (middle region)

H) Lower epidermis of the corolla (basal region / tube)

gl.h., glandular hair; n.gl.h., non-glandular hair. 


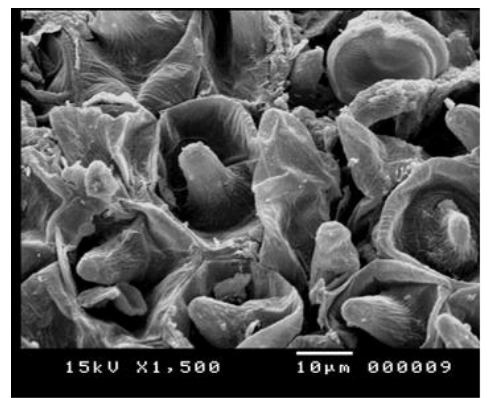

A

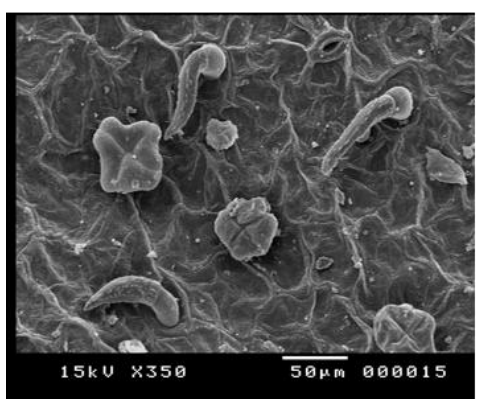

D

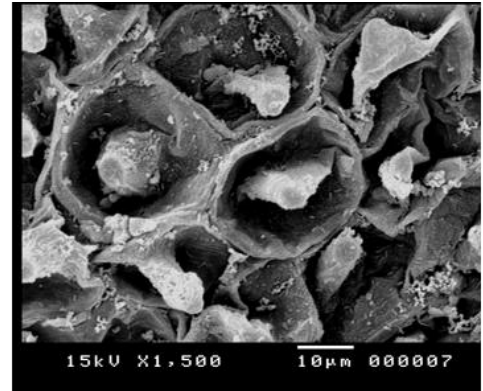

B

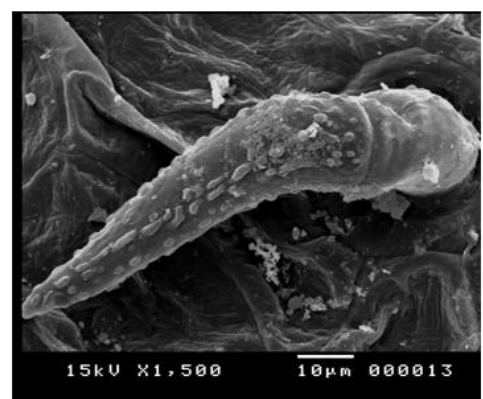

E

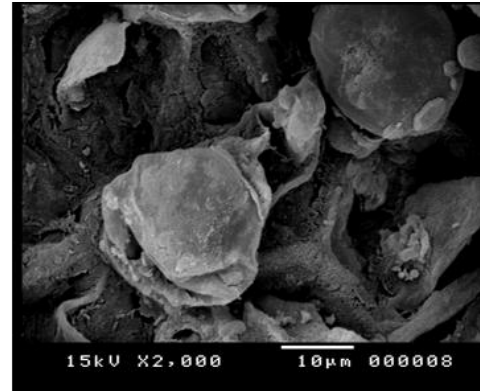

C

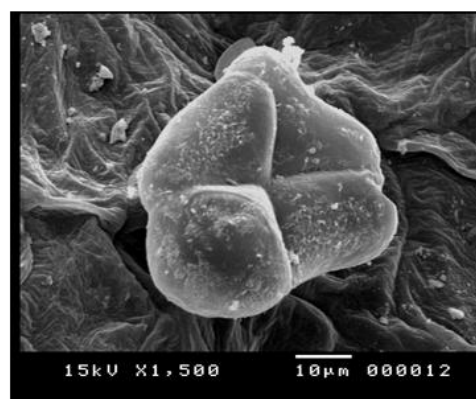

F

Fig. 11: Photos of the E.M. examination of the corolla of Gmelina philippensis Cham. (E.M.).

A) \& B) Upper epidermis of the corolla (apical and middle regions)

C) Glandular hair of unicellular stalk and bicellular head

D) Lower epidermis of the corolla (middle region)

E) Non-glandular bent hair

F) Glandular four-celled head hair 


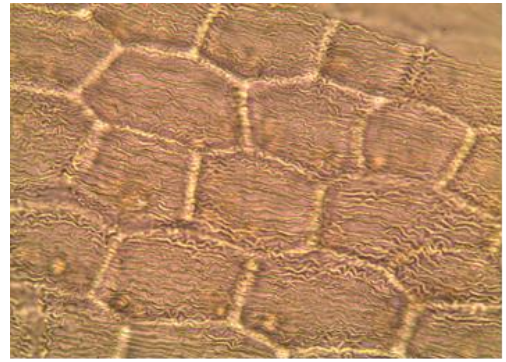

A

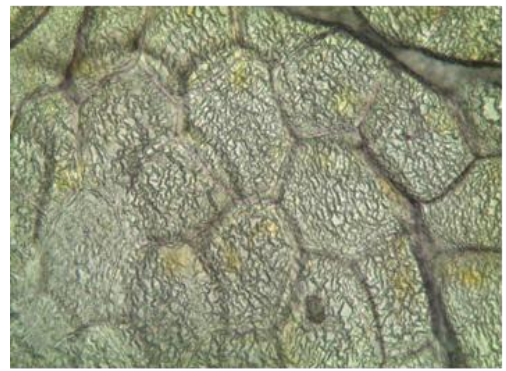

D

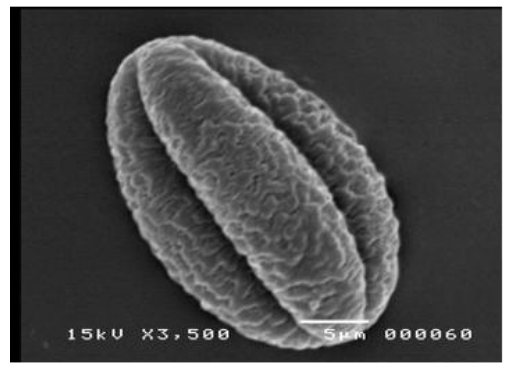

G

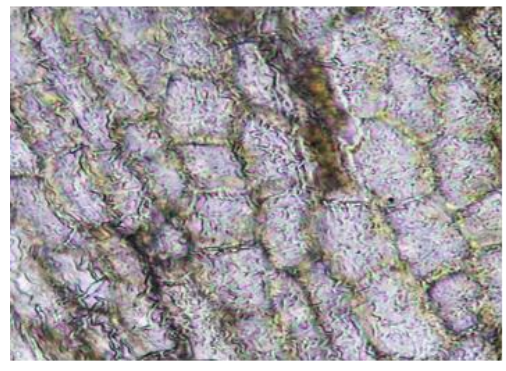

J

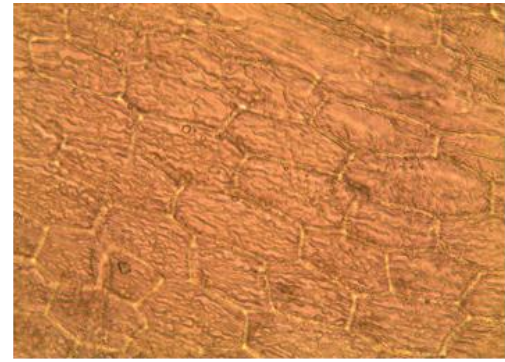

B

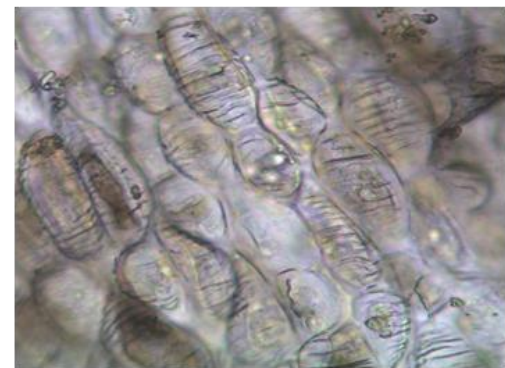

$\mathrm{E}$

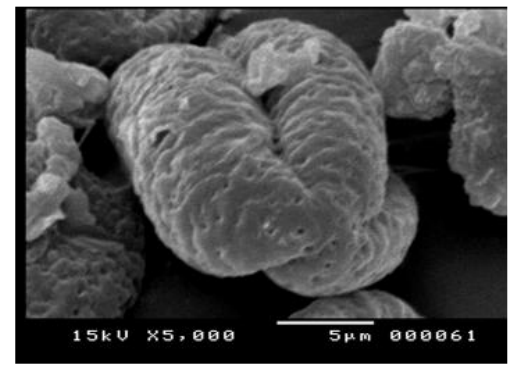

$\mathrm{H}$

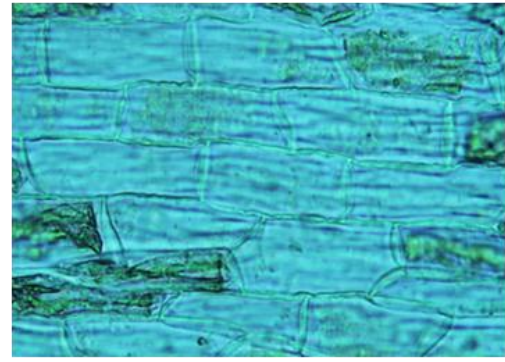

K

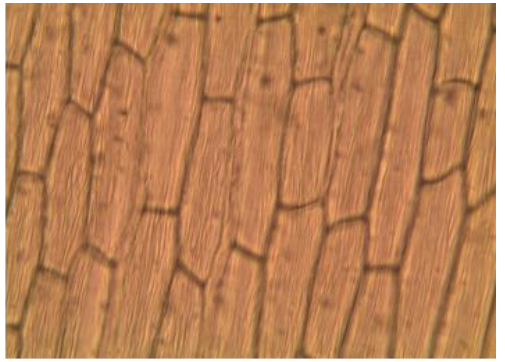

C

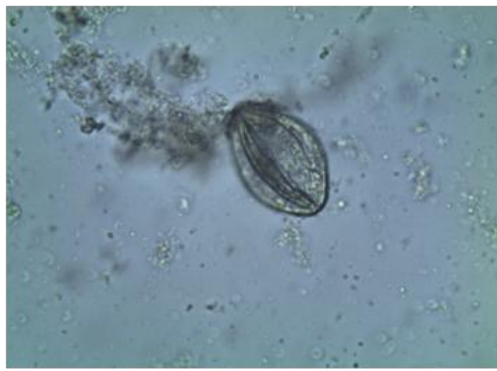

$\mathrm{F}$

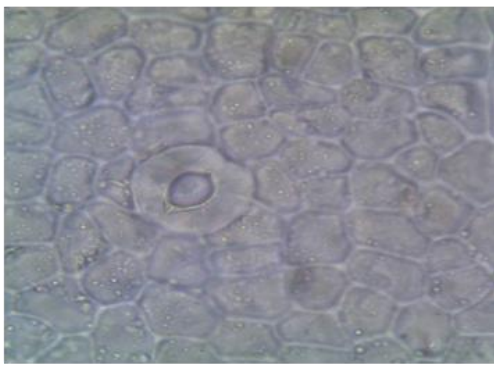

I

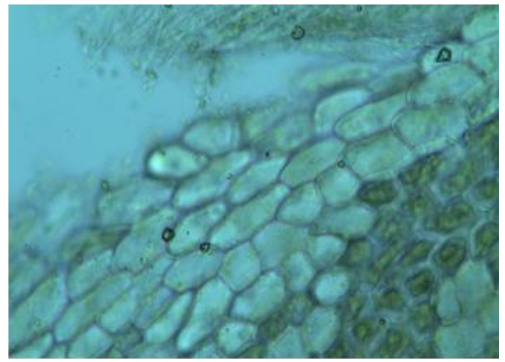

$\mathrm{L}$

Fig. 12: Photos of the microscopical examination of the androecium and gynoecium of Gmelina philippensis Cham. (x200).

A) Epidermis of filament (apical region)

B) Epidermis of filament (middle region)

C) Epidermis of filament (basal region)

D) Epidermis of anther

E) Fibrous layer of anther

F) Pollen grain

G) \& H) Pollen grain (E.M.)

I) Outer epidermis of ovary

J) Epidermis of style at the apical region

K) Epidermis of style at the middle and basal regions

L) Papillosed stigma 
The epidermal cells of the style in surface view vary in shape and size at different positions (Fig. 12J\&K). They are polygonal, nearly isodiametric at the apical region, rectangular at the middle and basal parts having slightly thick, beaded walls and covered with striated cuticle especially at the apical region.

The epidermal cells of the stigma in surface view (Fig. 12L) are polygonal, slightly elongated and papillosed.

\section{Micromorphology of the bracteole}

A transverse section in the bracteole is nearly concavo-convex in outline (Fig. $13 \mathrm{~A} \& \mathrm{~B}$ ), surrounded with an inner and outer epidermises enclosing in-between a wide mesophyll traversed by vascular strands. Both inner and outer epidermis in surface view (Fig. 13C\&D) appear as polygonal cells with nearly straight walls, covered with smooth cuticle. The epidermal cells carrying few non-glandular bicellular bent hairs on the inner surface but abundant on the outer surface, alongside glandular four-celled head glandular hairs are observed. The outer epidermal cells show anomocytic stomata. The mesophyll consists of narrow collenchymatous zone of about two rows, followed by wide parenchymatous zone and traversed by several vascular strands each consists of radiating xylem and phloem. The xylem is formed of spiral vessels. No starch or calcium oxalate are observed.

\section{Micromorphology of the rachis}

A transverse section in the rachis (Fig. $14 \mathrm{~A}$ ) is somewhat circular in outline and nearly similar to that in the moderate-aged stem. It consists of an outer epidermis followed by wide cortex consisting of collenchyma and parenchyma cells. The endodermis is not distinguished and the pericycle is formed of nearly continuous ring of parenchyma cells interrupted by groups of lignified fibres and few sclereids followed by collateral vascular bundle surrounding wide region of pith.

The epidermis in transverse section (Fig. 14B) consists of one row of nearly square cells covered with smooth cuticle. In surface view (Fig. 14C), they are polygonal, mostly isodiametric with straight anticlinal walls, covered with smooth cuticle and carry nonglandular bicellular bent hairs covered with warty cuticle.

The cortex (Fig. 14B) consists of about three rows of rounded collenchyma cells followed by about five rows of parenchyma cells. No starch or calcium oxalate crystals are observed.

The pericycle (Fig. 14B) is represented by a narrow zone consisting of thin-walled parenchyma cells interrupted by groups of fibres and few sclereids similar to those observed in the moderate-aged stem. Sclereids are nearly square to rectangular in shape with moderately thick lignified walls, wide pitted lumina.

The vascular system (Fig. 14B), is represented by a phloem consisting of thinwalled cellulosic parenchymatous elements. The cambium is formed of about three rows of thin walled, subrectangular, tangentially elongated and radially arranged cellulosic cells. The xylem consists of narrow zone of radially arranged elements of lignified vessels, wood fibers, tracheids and wood parenchyma. The vessels are traversed by uni- to triseriate slightly lignified medullary rays in addition to wood fibres and wood parenchyma.

The pith (Fig. 14B) is a wide central zone formed of rounded parenchymatous cells being beaded, pitted and lignified towards the center.

\section{The powder of the inflorescence}

The powdered inflorescence is yellowish brown in colour with faint aromatic odour and taste. It is characterized microscopically (Fig. $15)$ by the following fragments:

1- Fragments from the inner and outer epidermal cells of the calyx being polygonal in shape with slightly thick straight anticlinal walls, covered with smooth cuticle and show anomocytic stomata on the outer surface.

2- Fragments from the epidermal cells of the corolla, they are polygonal in shape with slightly wavy anticlinal walls and covered with papillosed cuticle at the inner surface, while those of the outer surface are covered with striated cuticle and show few anomocytic stomata.

3- Non-glandular uniseriate bicellular bent hairs covered with warty cuticle covering the outer epidermal cells of the calyx and corolla. Also, glandular hairs are present, consisting of unicellular stalk and bicellular, four or eight-celled head covering the outer epidermal cells of the calyx and corolla. 


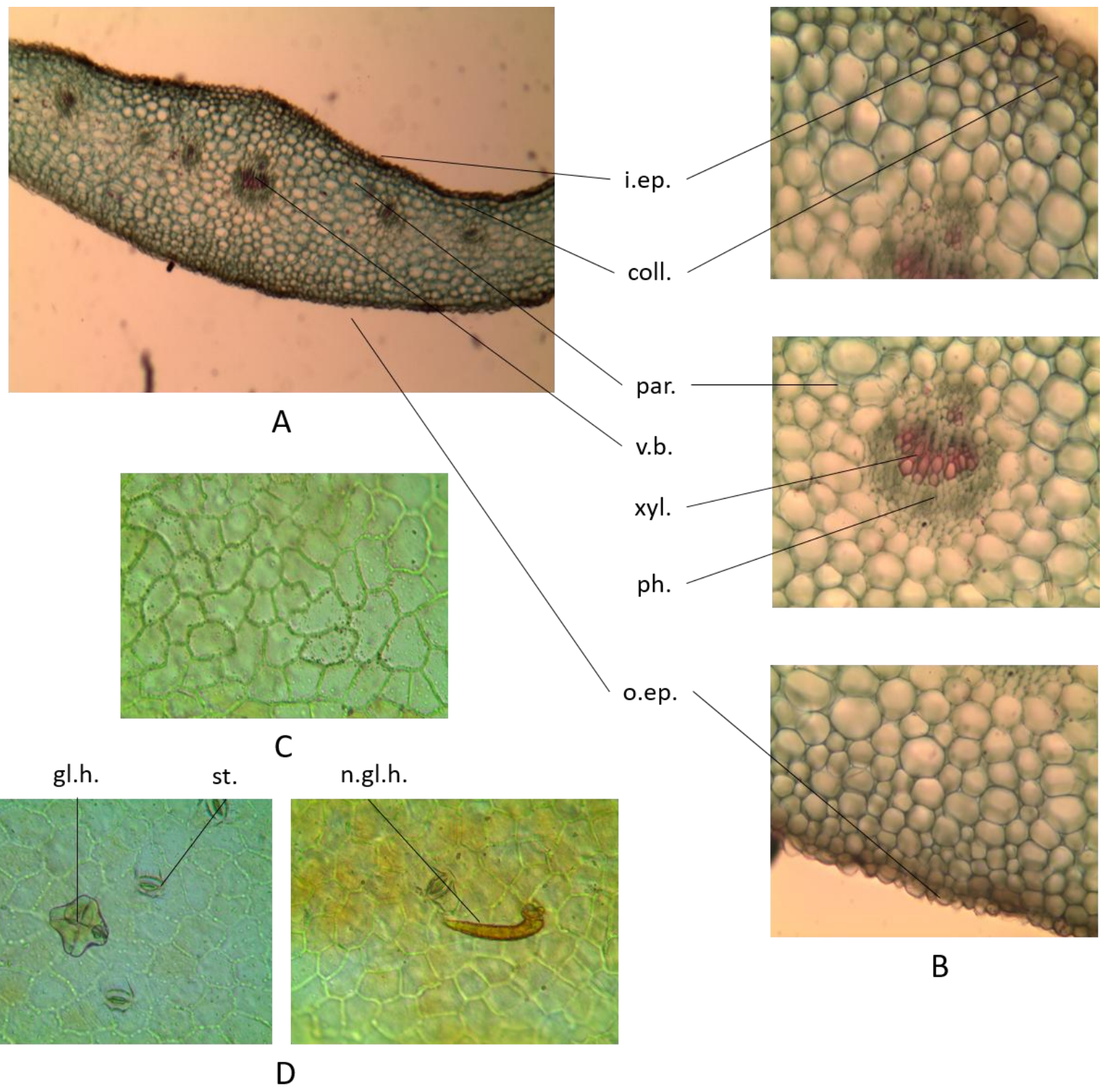

Fig. 13: Photos of the microscopical study of the bracteole of Gmelina philippensis Cham.

A) Diagrammatic T.S. in the bracteole (x40)

B) Detailed T.S. in the bracteole (x200)

C) Fragment of inner epidermal cells (x200)

D) Fragment of outer epidermal cells (x200)

coll., collenchyma; gl.h., glandular hair; i.ep., inner epidermis; n.gl.h., non-glandular hair; o.ep., outer epidermis; par., parenchyma; ph., phloem; st., stomata; v.b., vascular bundle; xyl., xylem. 


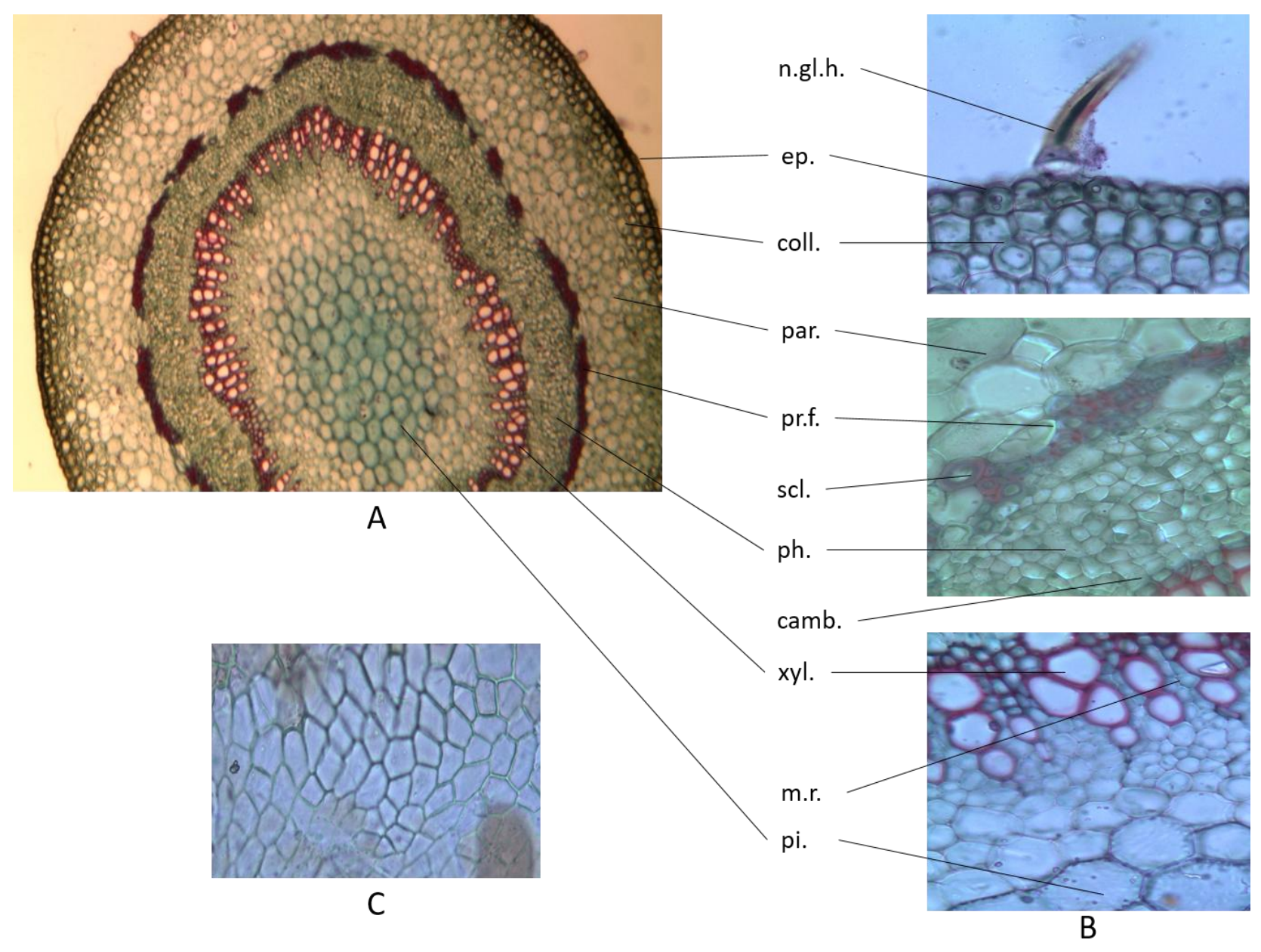

Fig. 14: Photos of the microscopical examination of the floral rachis of Gmelina philippensis Cham.
A) Diagrammatic T.S. in the rachis (x40)
B) Detailed T.S. in the rachis (x200)
C) Surface preparation of the rachis (x200)

camb., cambium; coll., collenchyma; ep., epidermis; m.r., medullary ray; n.gl.h., non-glandular hair; par., parenchyma; ph., phloem; pi., pith; pr.f., pericyclic fibres; scl., sclereids; xyl., xylem. 


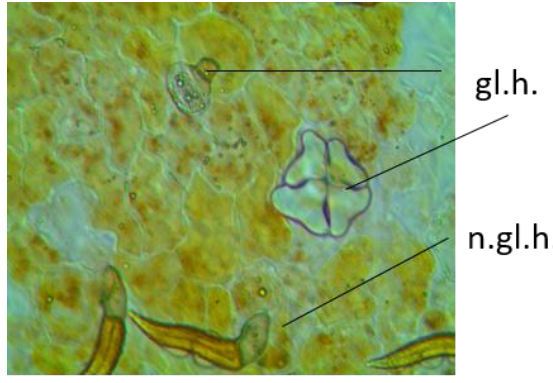

A

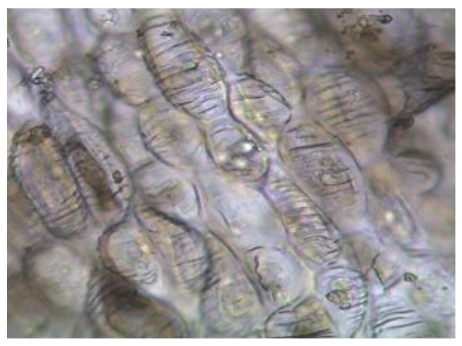

D

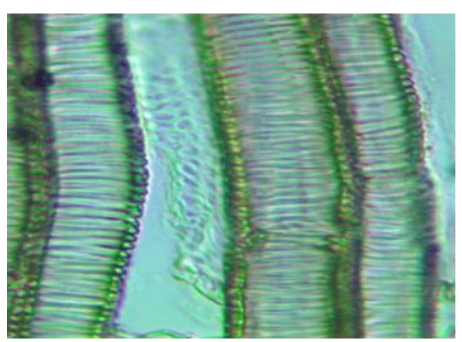

G

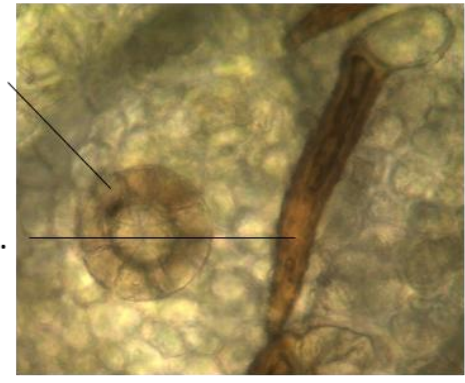

B

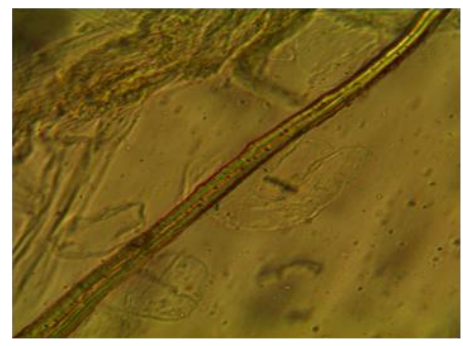

$\mathrm{E}$

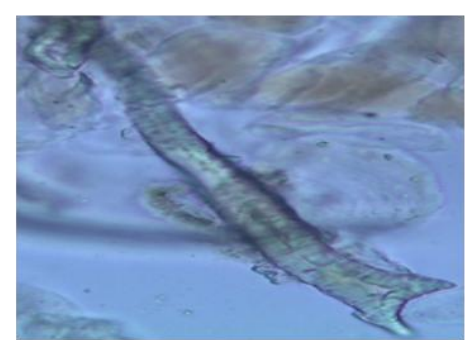

$\mathrm{H}$

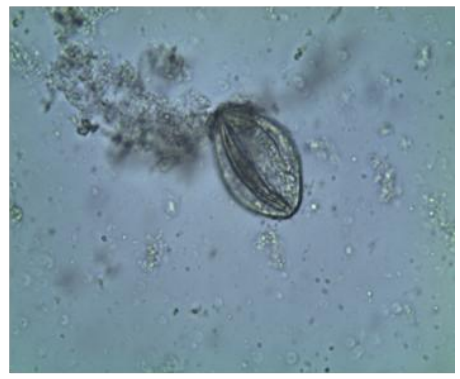

C

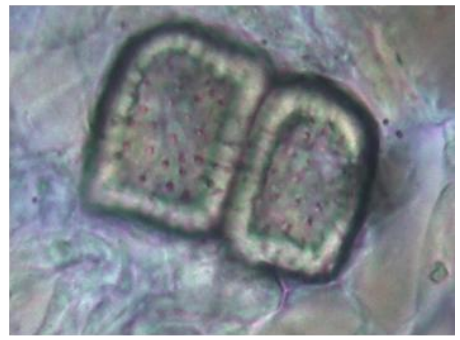

$\mathrm{F}$

Fig. 15: Photos of the microscopical examination of the powdered inflorescence of Gmelina philippensis Cham.

A) \& B) Glandular and non-glandular hairs (x200)

C) Pollen grains (x200)

D) Fibrous layer of anther (x200)

E) Pericyclic fibre (x100)

F) Sclereids (x200)

G) Xylem vessels (x200)

H) Forked wood fibre (x100)

gl.h., glandular hair; n.gl.h., non-glandular hair.

4- Tricolpate pollen grains, which are prolate in shape with bireticulate exine.

5- Fibrous layer of anther, showing beaded walls and transverse bar-like thickenings.

6- Lignified pericyclic fibres from the rachis with thick walls, narrow lumina and acute apices.
7- Sclereids from the rachis, that are square to subrectangular in shape with thick pitted lignified walls and narrow lumina.

8- Lignified xylem vessels with spiral and reticulated thickening.

9- Fusiform forked wood fibres from the rachis with thick walls and narrow lumina. 
Table 1: Microscopic measurements of the different organs of Gmelina philippensis Cham. (in micron).

\begin{tabular}{|c|c|c|c|c|c|c|c|c|c|c|c|c|}
\hline \multirow{2}{*}{$\begin{array}{ll} & \text { Item } \\
\text { Leaf } & \end{array}$} & \multicolumn{3}{|c|}{ Length } & \multicolumn{3}{|c|}{ Width } & \multicolumn{3}{|c|}{ Height } & \multicolumn{3}{|c|}{ Diameter } \\
\hline & & & & & & & & & & & & \\
\hline Upper epidermis & 38 & 50 & 64 & 30 & 35 & 45 & 17 & 19 & 21 & & & \\
\hline Lower epidermis & 35 & 47 & 61 & 17 & 32 & 40 & 9 & 12 & 16 & & & \\
\hline Neural epidermis & 66 & 78 & 107 & 31 & 39 & 39 & & & & & & \\
\hline Stomata & 15 & 19 & 23 & 9 & 12 & 14 & & & & & & \\
\hline Non-glandular hair & 100 & 170 & 220 & 17 & 24 & 31 & & & & & & \\
\hline Glandular hair & & & & & & & & & & 87 & 108 & 130 \\
\hline Palisade & 48 & 54 & 57 & 11 & 14 & 19 & & & & & & \\
\hline Pericyclic fibres & 747 & 880 & 1400 & & & & & & & 14 & 23 & 32 \\
\hline Xylem vessels & & & & & & & & & & 24 & 32 & 44 \\
\hline Wood fibres & 243 & 282 & 320 & & & & & & & 10 & 18 & 26 \\
\hline Tracheids & 200 & 230 & 300 & 17 & 20 & 22 & & & & & & \\
\hline Petiole & & & & & & & & & & & & \\
\hline Epidermis & 31 & 50 & 61 & 20 & 24 & 30 & 12 & 16 & 17 & & & \\
\hline Non-glandular hair & 90 & 130 & 200 & 16 & 24 & 29 & & & & & & \\
\hline Xylem vessels & & & & & & & & & & 29 & 34 & 37 \\
\hline Young stem & & & & & & & & & & & & \\
\hline Epidermis & 32 & 44 & 51 & 22 & 27 & 30 & 12 & 14 & 16 & & & \\
\hline Non-glandular hair & 90 & 130 & 180 & 17 & 22 & 30 & & & & & & \\
\hline Xylem vessels & & & & & & & & & & 13 & 23 & 30 \\
\hline $\begin{array}{l}\text { Moderate-aged } \\
\text { stem }\end{array}$ & & & & & & & & & & & & \\
\hline Epidermis & 37 & 45 & 55 & 20 & 26 & 30 & 12 & 14 & 17 & & & \\
\hline Pericyclic fibres & 690 & 887 & 1422 & & & & & & & 12 & 15 & 19 \\
\hline Square Sclereids & 35 & 42 & 47 & 26 & 36 & 42 & & & & & & \\
\hline $\begin{array}{l}\text { Rectangular } \\
\text { Sclereids }\end{array}$ & 50 & 71 & 99 & 37 & 50 & 67 & & & & & & \\
\hline Xylem vessels & & & & & & & & & & 26 & 36 & 41 \\
\hline Wood fibres & 259 & 481 & 622 & & & & & & & 13 & 15 & 18 \\
\hline Tracheids & 170 & 275 & 350 & 18 & 22 & 25 & & & & & & \\
\hline Inflorescence & & & & & & & & & & & & \\
\hline 1. The calyx & & & & & & & & & & & & \\
\hline Upper epidermis & 21 & 33 & 55 & 18 & 23 & 28 & & & & & & \\
\hline Lower epidermis & 20 & 30 & 43 & 10 & 15 & 23 & & & & & & \\
\hline Stomata & 24 & 32 & 45 & 14 & 21 & 30 & & & & & & \\
\hline Non-glandular hair & 150 & 190 & 230 & 17 & 20 & 28 & & & & & & \\
\hline Glandular hair & & & & & & & & & & 59 & 62 & 67 \\
\hline 2. The corolla & & & & & & & & & & & & \\
\hline $\begin{array}{l}\text { Upper epidermis } \\
\text { (apical region) }\end{array}$ & 29 & 37 & 41 & 20 & 24 & 29 & & & & & & \\
\hline $\begin{array}{l}\text { Upper epidermis } \\
\text { (middle region) }\end{array}$ & 29 & 38 & 48 & 13 & 19 & 23 & & & & & & \\
\hline $\begin{array}{l}\text { Upper epidermis } \\
\text { (basal region) }\end{array}$ & 113 & 164 & 196 & 26 & 37 & 42 & & & & & & \\
\hline $\begin{array}{l}\text { Lower epidermis } \\
\text { (apical region) }\end{array}$ & 25 & 36 & 45 & 15 & 18 & 22 & & & & & & \\
\hline $\begin{array}{l}\text { Lower epidermis } \\
\text { (middle region) }\end{array}$ & 47 & 55 & 67 & 17 & 21 & 15 & & & & & & \\
\hline $\begin{array}{l}\text { Lower epidermis } \\
\text { (basal region) }\end{array}$ & 126 & 142 & 155 & 24 & 37 & 41 & & & & & & \\
\hline Stomata & 35 & 44 & 50 & 26 & 30 & 35 & & & & & & \\
\hline Non-glandular hair & 80 & 130 & 180 & 10 & 12 & 14 & & & & & & \\
\hline
\end{tabular}




\begin{tabular}{|c|c|c|c|c|c|c|c|c|c|c|c|c|}
\hline Item & \multicolumn{3}{|c|}{ Length } & \multicolumn{3}{|c|}{ Width } & \multicolumn{3}{|c|}{ Height } & \multicolumn{3}{|c|}{ Diameter } \\
\hline $\begin{array}{l}\text { Glandular hair (4- } \\
\text { celled head) }\end{array}$ & & & & & & & & & & 70 & 74 & 80 \\
\hline $\begin{array}{l}\text { Glandular hair } \\
\text { (bicellular head) }\end{array}$ & & & & & & & & & & 27 & 32 & 47 \\
\hline 3- The androecium & & & & & & & & & & & & \\
\hline $\begin{array}{l}\text { Epidermis of } \\
\text { filament (apical } \\
\text { region) }\end{array}$ & 41 & 57 & 76 & 26 & 36 & 47 & & & & & & \\
\hline $\begin{array}{l}\text { Epidermis of } \\
\text { filament (middle } \\
\text { region) }\end{array}$ & 51 & 80 & 107 & 23 & 37 & 48 & & & & & & \\
\hline $\begin{array}{l}\text { Epidermis of } \\
\text { filament (basal } \\
\text { region) }\end{array}$ & 103 & 141 & 170 & 37 & 41 & 48 & & & & & & \\
\hline Epidermis of anther & 39 & 50 & 63 & 35 & 38 & 46 & & & & & & \\
\hline Pollen grains & 43 & 48 & 50 & 27 & 30 & 35 & & & & & & \\
\hline 4- The gynoecium & & & & & & & & & & & & \\
\hline $\begin{array}{l}\text { Outer epidermis of } \\
\text { the ovary }\end{array}$ & 31 & 44 & 55 & 20 & 29 & 40 & & & & & & \\
\hline Stomata & 60 & 67 & 71 & 60 & 65 & 69 & & & & & & \\
\hline $\begin{array}{l}\text { Epidermis of style } \\
\text { (apical region) }\end{array}$ & 28 & 37 & 41 & 17 & 23 & 27 & & & & & & \\
\hline $\begin{array}{l}\text { Epidermis of style } \\
\text { (middle region) }\end{array}$ & 63 & 72 & 80 & 20 & 23 & 30 & & & & & & \\
\hline $\begin{array}{l}\text { Epidermis of style } \\
\text { (basal region) }\end{array}$ & 29 & 38 & 52 & 17 & 23 & 31 & & & & & & \\
\hline Epidermis of stigma & 21 & 32 & 44 & & & & & & & & & \\
\hline Bracteole & & & & & & & & & & & & \\
\hline Inner epidermis & 33 & 56 & 67 & 25 & 31 & 41 & 11 & 16 & 20 & & & \\
\hline Outer epidermis & 40 & 56 & 71 & 31 & 42 & 47 & 11 & 17 & 21 & & & \\
\hline Stomata & 30 & 35 & 38 & 21 & 25 & 30 & & & & & & \\
\hline Xylem vessels & & & & & & & & & & 11 & 17 & 21 \\
\hline Rachis & & & & & & & & & & & & \\
\hline Epidermis & 23 & 34 & 48 & 17 & 22 & 28 & 16 & 19 & 21 & & & \\
\hline Xylem vessels & & & & & & & & & & 14 & 28 & 41 \\
\hline
\end{tabular}

\section{Conclusion}

The obtained macromorphological characters of $G$. philippensis Cham. complies with those published in the literature dealing with the characters of the plant belonging to the genus Gmelina ${ }^{9}$. A detailed microscopical examination of the studied organs concerning stomatal type, glandular, non-glandular hairs, type and characters of pollen grains are highly similar and agree with those reported for family Lamiaceae ${ }^{9,23 \& 24}$. The obtained data supports and confirms the transfer of this genus to family Lamiaceae.

\section{REFERENCES}

1- J. C. Willis and H. K. A. Shaw, "A Dictionary of the Flowering Plants and Ferns", Cambridge University Press, Cambridge, London, New York, $8^{\text {th }}$ Ed., 1973, p. 624.

2- C. L. Porter, "Taxonomy of Flowering Plants", Euasia Publishing House, New Delhi, $2^{\text {nd }} E d ., 1967$, pp. 380-382.

3- R. F. Throne, "Classification and geography of the flowering plants", The Botanical Review, 58 (3), 225-327 (1992). 
4- R. M. Harley, "Validation of the Name Lamioideae (Labiatae)", Kew Bulletin, 58 (3): 765-766 (2003).

5- K. Kubitzki, "The Families and Genera of Vascular Plants", Vol. VII, Berlin, Heidelberg: Springer Berlin Heidelberg, 2004, pp. 167-275.

6- N. B. Zahra and Z. K. Shinwari, "What is done and what has to be done in Lamiaceae, a review of phylogenetics", Peer J. Preprints, 4, e2277v1 (2016).

7- The International Plant Names Index (I.P.N.I), http://www.ipni.org/ipni/idPlant NameSearch.do (2005).

8- Kew Garden Plant List, http://www.theplantlist.org/1.1/browse/A/ Lamiaceae/ (2012).

9- R. de Kok, "A revision of the genus Gmelina (Lamiaceae)", Kew Bulletin, 67 (3), 293-329 (2012).

10- L. H. Baily, "The Standard Cyclopedia of Horticulture", The Macmillan Co., New York, $2^{\text {nd }}$ Ed., Vol. III, 1963, pp. 13521353.

11- L. M. Perry and J. Metzger, "Medicinal Plants of East and South Asia", The MIT Press, Cambridge, Massachusetts and London, England (1980).

12- K. R. Kirtikar, B. D. Basu, L. I. Colonel and An I. C. S., "Indian Medicinal Plants", Published by Lalit Mohan Basu, $2^{\text {nd }}$ Ed., Vol. III, 1935, pp. 1932-1934.

13- J. Xiong, X.-Y. Wu, P.-P. Wang, C. Lau, H. Fan, G.-L. Ma, Y. Tang, J. Li and J.-F. $\mathrm{Hu}$, "Acylated iridoid diglycosides from the cultivated endangered ornamental tree Gmelina hainanensis", Phytochem. Lett., 25, 17-21 (2018).

14- M. A. Ghareeb, H. A. Shoeb, H. M. F. Madkour, L. A. Refahy, M. A. Mohamed and A. M. Saad, "Antioxidant and cytotoxic activities of flavonoidal compounds from Gmelina arborea Roxb.", Global J. Pharmacol., 8 (1), 8797 (2014).
15- S. Falah, T. Katayama and T. Suzuki, "Chemical constituents from Gmelina arborea bark and their antioxidant activity", J. Wood Sci., 54 (6), 483-489 (2008).

16- J.-J. Chen, M.-J. Cheng, H.-R. Liao, P.-J. Sung, T.-C. Wang, T.-H. Chang and Y.-P. Lim, "Gmelinoiridoside, a new iridoid glycoside from Gmelina philippensis", Chem. Nat. Compd., 50 (6), 1005-1008 (2014).

17- D. O. Moronkola, I. A. Ogunwande, K. H. C. Baser, T. Ozek and G. Ozek, "Essential oil composition of Gmelina arborea Roxb., Verbenaceae, from Nigeria", $\boldsymbol{J}$. Essent. Oil Res., 21 (3), 264-266 (2009).

18- A. S. R. Anjaneyulu, A. M. Rao, V. K. Rao and L. R. Row, "Lignans of Gmelina asiatica", Phytochemistry, 14 (3), 824 (1975).

19- H. M. Sayed., A. S. Ahmed, I. SA. Khallaf and A. Asem, "Genetic profiling of Gmelina philippensis Cham." (under preparation).

20- L. Benson, "Plant Classification", Oxford \& IBH Publishing Co., New Delhi, Calcutta, Bombay (1970).

21- J. Hutchinson, "The Families of Flowering Plants", Oxford University Press, Oxford, $3^{\text {rd }}$ Ed., 1973, p. 624.

22- P. D. Cantino, R. M. Harley and S. J. Wagstaff, "Genera of Labiatae: Status and Classification. Advances in Labiatae", First International Conference on Labiatae, Royal Botanic Garden, Kew: Royal Botanic Gardens, 511-522 (1992).

23- A. El-Gazzar and L. Watson, "Labiatae: Taxonomy and susceptibility to Puccinia menthae Pers.", New Phytologist, 67 (3), 739-743 (1968).

24- Badamtsetseg, Bazarragchaa, L. S. Myoung and L. H. Yuon, "Pollen morphology of the family Lamiaceae in Mongolia", Journal of Korean Nature, 5 (2), 169-179 (2012). 


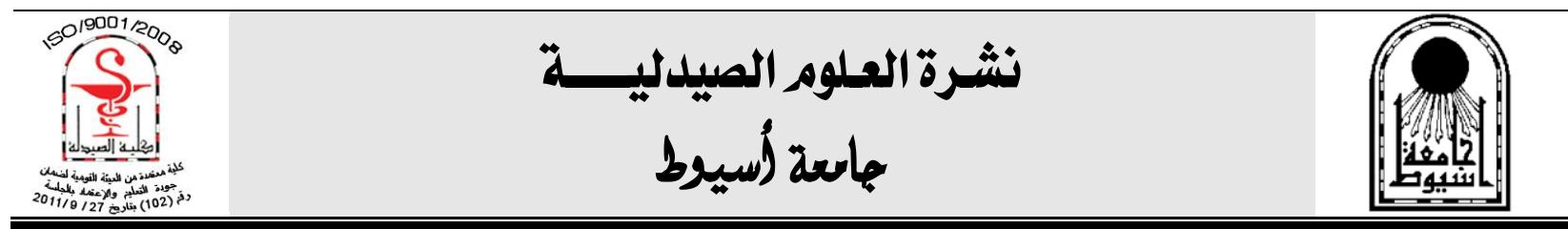

\section{توثيق الخصائص النباتية لنبات الجملينا فلبينس المزروع في مصر}

هناء محمد سيد - أماني سيد أحمد - إيمان سيد أحمد السيد خلاف - أيمن عاصم عبد المنعج.

$$
\text { قسم العقاقير ، كلية الصيدلة ، جامعة أسيوط ، مصر }
$$

ينتمي نبات الجملينا فلبينسس إلى العائلة الثفوية ، وقد كان يصنف قبل فيل ذلك كتابع للعائلة

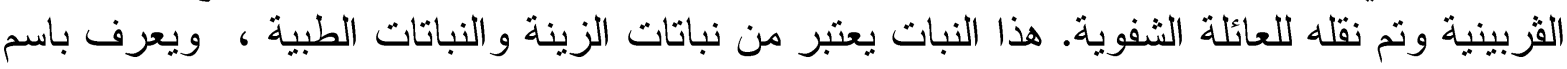

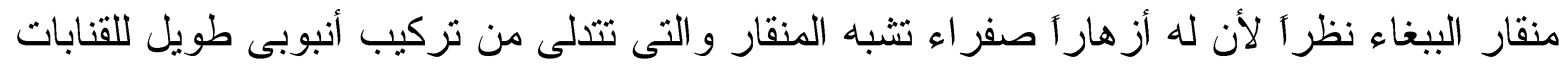

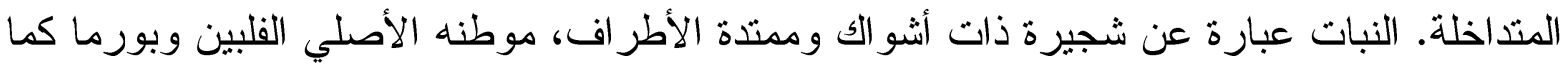

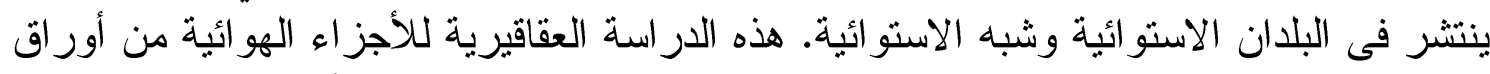

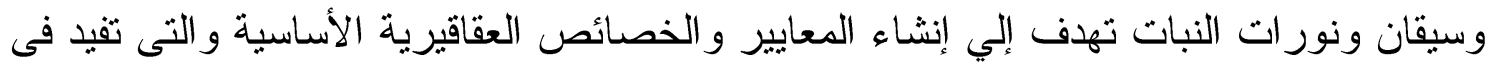

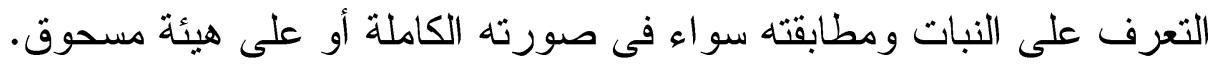

